\title{
Müştereklerin Çitlenmesi Ekseninde Kadınlar: Ekofeminist Perspektiften Türkiye'de Çevre Hareketleri
}

\author{
Women in the Axis of the Enclosure of Commons: Environmental \\ Movements in Turkey from the Ecofeminist Perspective
}

\section{Dalya Hazar Kalonya}

Pamukkale Üniversitesi Mimarlık ve Tasarım Fakültesi, Şehir ve Bölge Planlama Bölümü, Denizli

\section{ÖZ}

Ekofeminist perspektif tarafından yapılan yakın tarihli çalışmalar, toplumsal cinsiyet, çevre/doğa, doğal varlıklar, müşterekler ve çevre eylemleri arasındaki karşılıklı ilişkilere işaret ederken; biyoçeşitliliğin korunmasında kadınların küresel rolünü de tartışmaktadır. Kırsalda yaşayan ve geçimi doğal varlıklara bağlı olan kadınlar ile bitki biyoçeşitliliği ve tohumların korunması arasındaki belirgin ilişki yabancı literatürde sıklıkla ifade edilmektedir; ancak bu konu Türkiye'de henüz yeterince tartışılmamıştır. Kırsalda kadınlar, tohumların çeşitliliği ve sürekliliğinden, gıda döngüsü ve güvenliğinden, yem bitkilerinden, hayvancılıktan, ormancılıktan ve daha birçok üretim ve toplumsal yeniden üretim aracından sorumludur. Kadınların bu görünmez emeği, büyük tarım şirketlerinin dikte ettiği kısır monokültürler ile biyoçeşitliliğin kadimden beri süregelen, uzun erimli varlığı arasındaki çatışmanın tam ortasındadır. Buna ek olarak, ekofeminist perspektiften bakıldığında, doğal varlıkların ve/veya ekolojik müştereklerin çitlenmesine tepki olarak ortaya çıkan çevre eylemleri içerisinde kadınların oldukça görünür, hatta ön planda olduğu dikkat çekmektedir. Çalışma, ekofeminizm, müşterekler ve çevre hareketleri kavramlarına dair yapılan literatür taraması ve Türkiye'deki çevre hareketlerine dair yapılan medya analizi aracılığıyla çevre/doğa ve kadınlar arasındaki ilişkiyi müştereklerin çitlenmesi ekseninde tartışmakta ve CBS analiz araçlarını kullanarak Türkiye'deki çevre hareketlerini mekansallaştırmaktadır.

Anahtar sözcükler: CBS; çevre hareketleri; ekofeminizm; kırsal politikalar; müşterekler; toplumsal cinsiyet; Türkiye.

\section{ABSTRACT}

Recent studies by ecofeminist perspective refer to the interrelations between gender, environment/nature, natural assets, commons and environmental movements while also discuss the global role of women within the biodiversity protection. The significant relation between the plant diversity and seed protection and the rural women whose livelihood depend on the natural assets is stated in the foreign literature; however, this issue is not adequately discussed in Turkey yet. Rural women are responsible for the seed diversity and sustainability, food cycle and safety, forage crops, husbandry, forestry and many other production and common reproduction tools. This invisible labor of women is in the midst of the conflict between the barren monocultures dictated by major agricultural companies and the immemorially lasting and long-range asset of biodiversity. In addition, from the ecofeminist perspective, it is noteworthy that women are highly visible and even at the forefront in the environmental movements that emerge as a reaction to the enclosure of the natural assets and/or ecological commons. The study discusses the relationship between the natural resources and women within the axis of the enclosure of the commons through the literature review on the concepts of ecofeminism, commons and environmental movements; and spatializes the environmental movements in Turkey by using GIS analyst tools through the media analysis.

Keywords: GIS; environmental movements; ecofeminism; rural policies; commons; gender; Turkey. 


\section{Giriş}

Doğal varlıklar ve/veya ekolojik müşterekler üzerindeki çitleme ve tahribat baskısı, çevrecilik, ekofeminizm ve müşterekler yazılarının ortak araştırma alanıdır. Çevre hareketleri de bu baskılar sonucunda reaktif olarak ortaya çıkan müşterekleştirme girişimleri/pratikleri olarak ele alınmaktadır. Müşterekler en genel anlamıyla "sahip olduğumuz ve birlikte yaptığımız her şey” olarak tanımlanmaktadır. Son yıllarda, Türkiye'nin kırsal ve kentsel alanlarında çitleme yoluyla müştereklere erişim hakkının kısıtlanması karşısında, sıklıkla küçük ölçekli ve yerel odaklı direnişlerin ortaya çıktığı görülmektedir. Müşterekler, doğal (ekolojik) müşterekler ya da yapay (kentsel) müşterekler olarak ikiye ayrılmakta ve gelenek, dil, kolektif bilgi gibi soyut varlıkları kapsamaktadır (Adaman ve diğ., 2017).

Müşterekler üzerinde süregelen çitleme baskısı, I7. yüzyılda İngiltere kırsalında başlayan ve ilkel birikimi oluşturan, "devlet ve sermaye iş birliği ile özel mülkiyete çevirme yoluyla alıkoyma" olarak da tarifleyebileceğimiz çitleme hareketlerine dayanmaktadır. Marx (1867) bu süreci "sermayenin kırsal müştereklere saldırısı" olarak tarif etmiştir. Müştereklerin çitlenmesine karşı yerelde direnen topluluklarla başlayan çevre hareketleri ise yine 17. ve 19. yüzyıllar arasına temellenmektedir (Garner, 1996). Günümüzde müşterekler üzerinde süregelen temel problem halen özelleştirme ve dönüşüm baskısıdır. Özellikle 1980'li yıllardan itibaren tarım alanları, ormanlar, meralar, kıyılar vd. doğal alanların, neoliberal kentleşme ve inşaat, turizm, maden ve enerji sektörleri önceliğinde özelleştirilmesi, tohumların ve genlerin patentlenmesi "yeni bir çitleme harekâtı" olarak ifade edilmektedir (Penpecioğlu, 2013; Walljasper, 2014; Benlisoy, 2014; Christophers, 2018). Çitleme hareketleri devam ettiği sürece, müşterekleştirme pratikleri olarak çevre hareketleri ve buna paralel dava süreçleri de kuşkusuz devam edecektir.

Müşterekler ve müşterekleştirme pratikleri, mekânla ve insan bedeniyle kurulan paylaşımlar olarak, kentleri ve toplumu biçimlendirme gücü olan hareket türleridir (Stavrides, 2020). Bu bağlamda, çevre hareketleri müşterekleştirme pratikleri olarak kabul edilebilir çünkü çevre/doğa müşterek konulardır ve çevre hareketleri sıklıkla müştereklerin savunusu amacı taşımaktadır. Müşterekler ve çevre hareketleri, politik ekonomi (ve politik ekoloji) bağlamında daha çok tartışılması gereken konulardır. Politik ekoloji, sosyal yapıların ve organizasyonların çevre/doğa ile etkileşimini, tarihsel süreçte ekolojik krizlere verilen yanıtları ve çevre hareketleriyle ortaya çıkan temel politik eğilimleri inceleyen bir bilim alanıdır. Politik ekolojistler, çevre/doğanın içkin değeri üzerinde durmakta ve ekolojik bilinci olan bir toplum oluşturmayı amaçlamaktadır. Politik ekoloji alanında, derin ekolojistler, eko-sosyal demokratlar, liberal eko-sosyalistler, sosyal ekolojistler ve feminist politik ekolojistler gibi birçok ayrım bulunmaktadır (Dobson, 1995; Heynen ve diğ., 2006; Akbulut, 2014; Roussopoulos, 2015).
Politik ekolojistler, neoliberal politikalar sebebiyle çevre/doğa üzerinde ortaya çıkan baskılara odaklanırken; feminist politik ekolojistler, doğal varlıklar ve/veya ekolojik müşterekler üzerinde karar alma süreçlerindeki toplumsal cinsiyet rollerine ve güç ilişkilerine ve kadınların toplumsal konumlarının cinsiyetleri dışında din, sınıf, etnik köken vb. ile de ilişkin olduğunu savunan kesişimselliğe odaklanmaktadır. Dolayısıyla, bir toplum hakkında konuşmadan o toplumun müşterekleri hakkında konuşmak da mümkün değildir (Sato ve Alarcon, 2019). Nightingale (2019), müşterekleştirme pratiklerini, eko-merkezci sosyo-doğal süreçler olarak tariflemektedir. Toplumsal cinsiyet, ırk, etnik köken, kast, yaş ve engellilik durumu gibi kesişimselliklerin hiçbiri güç ilişkileri sebebiyle ortaya çıkan çatışmalardan bağımsız değildir. Bu sebepten, müşterekleştirme pratikleri de insanlar ve diğer canlıları kapsayan bir güç hareketidir (Nightingale, 2019).

Ekolojik müştereklerin yerel ve parayla ölçülemez kullanım ve kültürel değeri sıklıkla karar vericiler tarafından azımsanmaktadır. Özellikle az gelişmiş ve gelişmekte olan ülkelerdeki birçok kırsal toplulukta, yiyecek, ilaç, giysi, barınak, alet ve gelir sağlayan doğal varlıklar kadınların temel zenginliğidir ve bu kaynaklara erişimlerinin sürekliliği kadınların toplumdaki konumları ve refahları için önemlidir. Bir diğer önemli nokta, kadınların sürdürülebilir kalkınma stratejileri ve karar verme süreçlerine dahil olmaları gerekliliğidir; çünkü biyoçeşitlilik ancak doğal varlıkların sürdürülebilir kullanımına ve bu kullanımdan sağlanan yararların adil ve eşit paylaşımına ve yerel örtük bilgiye önem verildiği sürece korunabilir. Buna ek olarak, doğal varlıklara ve/veya ekolojik müştereklere erişimin kısıtlandığı ve çitlendiği durumlar karşısında gösterilen tepkilerin dünyada ve Türkiye'de benzerlik gösterdiği görülmektedir (Hazar, 2020).

Yapılan çalışma, toplumsal hareketler içerisinde önemli bir yere sahip olan ekofeminizm ve müşterekler literatürleri kapsamında Türkiye'de ekolojik müştereklerin çitlenmesi girişimleri karşısında ortaya çıkan çevre hareketlerine ve kadınların bu hareketlerdeki görünürlüğüne odaklanmaktadır. Çalışmanın ilk aşamasında, ekofeminizm, müşterekler ve çevre hareketleri kavramlarına dair literatür taraması yapılmıştır. Çalışmanın ikinci aşamasında, 2009-2019 yılları arasında Türkiye'de basına yansıyan çevre hareketleri Medya Takip Merkezi (MTM) arşivinden “çevre eylemleri” anahtar kelimesiyle aratılmış ve çevre hareketlerinin konuları, sayıları, yerleri ve kadınların bu hareketlerdeki görünürlüğü içerik analiziyle değerlendirilmiştir. Çalışmanın son aşamasında, Coğrafi Bilgi Sistemleri (CBS) analiz araçları kullanılarak Türkiye'deki çevre hareketleri haritalandırılmıştır.

\section{Ekofeminist Yaklaşımlar}

Ekoloji kelimesi ilk olarak Alman biyolog Haeckel (1866) tarafından "türlerin karşııılı bağımlılığı yararına çalışan bir 
bilim alanı" olarak tanımlanmıştır. Politik ekoloji ise Coğrafya altında ortaya çıkan ve çevre ile karşılıklı etkileşim içinde bulunan sosyal yapılar ve toplumsal organizasyonları inceleyen bir araştırma alanıdır (Elmhirst, 20II). Politik ekoloji yaklaşımı, çevrenin/doğanın devlet tarafından yönetiminin tarihini, ekolojik krizlere verilen yanıtları ve çevre hareketleriyle ortaya çıkan temel politik eğilimleri tartışmaya açmaktadır. Politik ekolojistler, çevre/doğanın içkin değeri üzerinde durmakta ve ekoloji bilinci olan bir toplum oluşturmayı amaçlamaktadır. Politik ekoloji alanı, derin ekolojistler, eko-sosyal demokratlar, liberal eko-sosyalistler, sosyal ekolojistler ve ekofeminist literatürün ikinci ayrımında konumlanan feminist politik ekolojistler gibi birçok ayrım içermektedir (Dobson, 1995; Heynen ve diğ., 2006; Roussopoulos, 20I5).

1970'li yılların ortalarında ortaya çıkan ekofeminist yaklaşımlar, çoğulcu ideolojiler benimsemekte ve ekolojik krizlere farklı bakış açılarıyla yaklaşmaktadır. Ekofeminist literatürde üç temel ayrım bulunmaktadır; (I) özcü ekofeministler, (2) sosyal ekofeministler, (3) ortaklık etiği savunucuları. Birinci ayrım ekofeministler, kadınların erkeklerden farklı psikolojik ve biyolojik özellikleri olması sebebiyle kadınlar ve çevre/ doğa arasında doğrudan ve yakın bir ilişki olduğunu savunur (ör. yeryüzü ana Gaia). Kadınların yereldeki gücünü arttırmayı savunan özcü ekofeministler, toplumsal ve ekolojik krizlerin temellerinin kapitalizmden çok daha önceye, ataerkiye dayandığını savunur ve kadınlık değerlerinin yüceltilmesiyle toplum ve çevre/doğa arasında bütünlükçü bir bakış açısı oluşturmayı amaçlar. Ancak özcü ekofeministler, irrasyonel düşüncelerden etkilendikleri, biyolojik ve tinsel indirgemecilikleri, bilimsel ve kültürel ilerlemeleri ve değişkenleri reddetmeleri, erkeklerin doğayı korumaya yönelik bir siyaset geliştiremeyeceği iddiaları ve kadının dişiliği üzerinden geleneksel cinsiyet rollerini pekiştirmeleri sebebiyle ikinci ayrım ekofeministler tarafından eleştirilirler. Örneğin, dişi ilkeyi savunan Shiva'nın Hindistan kırsalında yaptığı çalışmalar (Shiva, 1992), üçüncü dünya ülkelerindeki sömürgecilik deneyimini ve Batı tarzı kalkınma sebebiyle marjinalleştirilen kırsaldaki kadınlar öncesinde de var olan toplumsal eşitsizlikleri göz ardı etmesi sebebiyle eleştirilmektedir (Agarwal, 1992; Zein-El Abdin, 1996; Çetin, 2005).

İkinci ayrım ekofeministler, kadınların erkeklerden farklı psikolojik ve biyolojik özellikleri olduğu görüşünü reddeder ve kadın ve doğanın ikili sömürüsünün maddi temellerini ortaya koymaya çalışır. Sosyal ekofeministler, feminist politik ekolojistler ve Marksist feministlerin kesişiminde bulunan ikinci ayrım ekofeministler, ekolojik krizlerin merkezine salt toplumsal cinsiyet kaynaklı tahakkümleri değil; kapitalist ataerki, din, ırk, sosyal sınıf vb. kesişimsellikleri de dahil eder. İkinci ayrım ekofeministler, toplumsal baskılar ortadan kaldırılmadan, insanlığın ya da çevrenin/doğanın özgür olamayacağını savunur. Özellikle az gelişmiş ve gelişmekte olan ülkelerde yapılan çalışmaların sosyal ekoloji (politik ekoloji) çerçevesinde, ikinci ayrımda yer aldığı görülmektedir. İkinci ayrım ekofeministler, sistemin tahakkümü ile gerçek anlamda mücadele etmenin ancak geniş ölçekte toplumsal güçlere ve mevcut ekonomik sisteme meydan okuyabilecek kolektif bir toplumsal hareketle mümkün olduğunu düşünür (Biehl, 199I; Çetin, 2005; Roussopoulos, 2015).

Üçüncü ayrım ekofeministler ise birinci ve ikinci ayrım ortasında durmaya çalışır. Birinci ayrımın kadınların erkeklerden farklı psikolojik ve biyolojik özellikleri olduğu görüşünü paylaşırken, çevre/doğa ve kadın sorunlarına çözüm olarak kadınsı değerleri yücelten yeni bir ortaklık etiği önerir. Bu süreçte, ikinci ayrımın savunduğu kesişimselliklerden bağımsız olarak tüm dünyada erkeklerin kadına ve doğaya birlikte saldırdığını ve hükmettiğini varsayar, ancak kadınların da doğaya tahakküm ettiği, zarar verdiği durumlar olabileceğini göz ardı eder (Çetin, 2005).

Ancak ekofeminizmin üç ayrımı da doğa/çevre koruma eylemini, biyoçeşitliliği korumayı amaçlayan bir toplumsal cinsiyet ekseninde değerlendirir. Birinci ayrımdan Vandana Shiva ve ikinci ayrımdan Maria Mies'ın birlikte yazdıkları Ekofeminizm (1993), bu bağlamda ortak kaygılarını dile getirmektedir. Elbette bu kaygının öncelikle yaşam alanları tarıma ve doğal varlıklara bağı olan, az gelişmiş ve gelişmekte olan ülkelerin kırsal alanlarında yaşayan kadınlar için geçerli olduğu söylenebilir. Özellikle ekofeminist yaklaşımların ikinci ayrımı; (I) çoklu kullanımları ve değerleri, (2) çoklu aktörleri, ilişkileri, insanlara ve çevre ekosistemlere aracılık eden farklı organizasyonları ve (3) fiziksel ve mekânsal ilişkinin peyzaj ve günlük yaşam pratikleriyle ilişkisini tanımlama kapasitesine sahiptir (Mies ve Shiva, 1993; Rocheleau, 1995).

Ekofeminist literatüre yönelik eleştirilerin başında, hangi ayrım içerisinde olursa olsun kadınların tek bir kategori içerisinde ele alınması ve renkli ırktan olan kadınların yaşadıkları deneyimlerin göz ardı edilmesi gelmektedir. Renkli ırktan kadın bedenlerinin çevre/doğa ile özdeşleştirilerek erkekler tarafından tahakküm altına alınmasının en açık örneği 19. yüzyılda Amerika'da köle kadınlar üzerindeki uygulamalardır. Bir diğer çarpıcı örnek ise, metalaştırılan bedeni sergilenmek için Avrupa'ya getirilerek bir vahşi hayvan bakıcısına satılan ve nihayetinde bir müzede sergilenen Sarah (Saartije) Baartman'ın hikayesidir (Mothoagae, 20I6). Bu bağlamda çevreye/doğaya ve kadına tahakküm süreçlerinin diğer kesişimsellikler göz ardı edilerek salt toplumsal cinsiyet ekseninde ele alınmasının yeterli olmayacağı anlaşımaktadır (Çetin, 2005; Mollett ve Faria, 20I3).

İkinci ayrım ekofeministler içerisindeki feminist politik ekolojistler için toplumsal cinsiyet, kaynakların erişilebilirliği ve kontrolü için, sınıf, kast, ırk, kültür ve etnik köken vb. kesişimselliklerle entegre olan kritik bir değişkendir. Toplumsal cinsiyet ve kaynak erişimi, mülkiyetin cinsiyetçi etkileri, müşterekler, çitleme hareketleri, yerinden yönetimli, iyileştirici geleneksel yöntemler ve çoklu kullanım haklarına dair çalışmalar, prensipleri ilk olarak Rocheleau ve diğ. (1996) tarafından belirlenen feminist politik ekoloji alanı kapsamındadır. $\mathrm{Bu}$ alandaki çalışmalar özellikle kırsalda sürdürülebilir yaşam 
alanları oluşturmak için üç temel konuya odaklanılmaktadır: (I) cinsiyetçi çevre bilinci, (2) cinsiyetçi çevre hak ve sorumlulukları, (3) tabandan gelen halk aktivizmi.

Yakın gelecekte tartışılması öngörülen üç temel feminist politik ekoloji alanı ise; (I) az görünür feminist ölçek kavramsallaştırmaları ve ilişkisellikleri (ör. insan bedeni, hanehalkı); (2) bedensel feminizmin gücü ve kesişimsellikleri; (3) feminist politika kavramsallaştırmaları ve politik ekolojide özne türetimidir (Rocheleau ve diğ., 1996; Elmhirst, 20I I).

\section{Ekofeminist Literatürde Müşterekler}

Ekofeministlerin müşterekler alanındaki çalışmaları otuz yıldan fazla zamandır devam etmektedir (Mies ve Shiva, 1993; Agarwal, 1992; Rocheleau ve diğ., 1996). Feminist politik ekolojistlerin son yıllardaki çalışmaları, toplumsal cinsiyet, çevre/ doğa ve müştereklerin çitlenmesi karşısında ortaya çıkan çevre eylemlerindeki toplumsal cinsiyet rolleri arasındaki farklılıklara işaret etmekte ve yerel sürdürülebilir kalkınma içinde kadının küresel rolünü tartışmaktadır (Rocheleau, 1995). Ayrıca son yıllarda müşterekleri neoliberal politikaların karşısında bir alternatif olarak konumlandıran çalışmalar ve müşterekleştirme pratiklerini odağa alan çalışmalar da yapılmaya başlanmıştır (De Angelis, 2007; Linebaugh, 2008; Bollier ve Helfrich, 20I5; Gibson-Graham ve diğ., 2016; Stavrides, 2016).

Müşterekler, "kamu kullanımına ve toplumun ücretsiz erişimine açık, kolektif mülkiyete sahip somut ve soyut varlıklar" olarak tariflenmektedir (Santos Junior, 20I4). Müşterekler, hava, su, orman ya da tohum gibi ekolojik müşterekler; kamu malları gibi yapay (kentsel) müşterekler; gelenek, dil, kolektif bilgi gibi soyut müşterekleri kapsamaktadır (Ostrom, 20l0; Adaman ve diğ., 2017).

Kaynak kötümserci bir ekolojist olan Hardin (1968), Müştereklerin Trajedisi isimli çalışmasında, kâr maksimizasyonu gözeten bireylerden oluştuğunu kabul ettiği çobanlar ve aşırı otlatılan meralar örneği üzerinden müştereklere kısıtlı erişim ve optimum nüfus ihtiyacından bahsetmiş ve müştereklerin korunmasının yalnızca iki şekilde mümkün olabileceğini söylemiştir: özelleştirme ve devlet kontrolü. Hardin'in önerisi, sermayenin müşterekleri özelleştirme girişimlerine teorik bir gerekçe sunduğu iddiasıyla eleştirilmiştir (Harvey, 20I2).

Buna karşılık Elinor Ostrom (1990), müştereklerin, müşterek kullanıcılar tarafından sürdürülebilir şekilde kullanılacağı bir iç denetim mekanizması kurulabileceğini ve halihazırda buna dair birçok örnek bulunduğunu kanıtlamıştır. Ostrom'un kolektif eylem teorisinde müşterek kullanıcılar, yabancıları (diğerlerini) müştereklerinden uzak tutma hakkı olan iyi tanımlanmış bir grup olarak tariflenmiştir (ör. belirli bir mevsimde belirli bir bölgede avlanan balıkçılar, hayvanlarını merada otlatan köyl köyler) (Ostrom, 1990; Angus, 2008; De Angelis and Harvie, 20I4). Ostrom, kolektif eylem teorisiyle Nobel Ekonomi Ödülü (2009) kazandığında, erkek egemen siyasi bilimler ve iktisat alanlarında tartışmalara yol açmıştır. Yine de Ostrom'un müştereklere ekofeminist perspektiften yaklaştığı söylenemez.

Ostrom'un teorisi müşterek kullanıcılarının ve içinde bulundukları toplumun/topluluğun tanımının belirsizliği sebebiyle eleştirilmiştir. İlk eleştiri, ideal koşullarda homojen bir topluluktan bahsetmenin mümkün olmayacağı ve müştereklerin yönetimi süresince, toplumsal cinsiyet, sınıf, ırk, etnik köken gibi kesişimsellikler bağlamında ortaya çıkabilecek olası eşitsizlikler hakkındadır. Buna ek olarak, çitleme hareketleri kapitalizmin içkin devinimidir ve müştereklerin neoliberal politikalara çözüm üretebilmesi için bir sistem eleştirisi gerekmektedir. Bu sebeple, müşterekler kolektif eylem teorisinden daha kapsamlı bir politik ekonomi perspektifinden ele alınmalıdır (Akbulut, 20I4; Adaman ve diğ., 2017).

Müşterekleri (yeniden) yaratma süreci olarak da tariflenen müşterekleştirme pratiklerini ekofeminist perspektiften inceleyen ikinci ayrım çalışmalar, gündelik yaşam pratiklerine, sosyal ilişkilere, tasarlanmış mekanlara ve toplumsal yeniden üretim alanlarına odaklanmakta ve müştereklerin metalaştırılma riskine karşı bir noktada konumlanmaktadır (Sultana, 2009; Federici, 20I I; Nightingale, 20I I; Elmirst, 2015; Clement ve diğ., 2019). Toplulukların doğal varlıkların yönetimindeki rolüne odaklanan tartışmalar, neoliberal politikaların yarattı̆̆ı baskıya odaklanan politik ekolojistler ile toplumsal cinsiyet rollerine odaklanan feminist politik ekolojistlerin iklim değişikliği ve çevre söylemlerindeki kesişimselliklere bağlı güç ilişkilerine işaret etmesiyle zenginleşmektedir (Rocheleau, 2008; Ahlers ve Zwarteveen, 2009; Harris, 2009).

İkinci ayrımda bulunan feminist politik ekoloji, müşterekleri bir analiz nesnesi olarak görmekte ve doğal varlıklara ve/veya ekolojik müştereklere, mülkiyete, gündelik yaşam pratiklerinin birbirine bağlı mekânlarına ve hanehalkının durumuna odaklanmaktadır. Feminist politik ekoloji ayrıca müşterekleri; biyofiziksel müşterekler, bilgi müşterekleri, kültürel müşterekler ve toplumsal müşterekler olarak ayırmakta ve müşterekleştirme pratiklerindeki dönüştürücü potansiyeli ortaya koymaktadır (Clement ve diğ., 2019).

Feminist tartışmaların yanı sıra post-kapitalist topluluk ekonomisi çalışmaları da müşterekler tartışmalarıyla ilişkilendirilmektedir. Sato ve Alarcon (2019), bir post-kapitalist feminist politik ekoloji (FPE) yaklaşımını tarifleyerek, genellikle sınıf farkılıklarını göz ardı eden sermaye merkezli müşterekler tartışmalarının sınırlı vizyonunu genişletmiştir.

Marksist feministler ise müştereklerin yalnızca metalaştırılabilir kaynaklara indirgenemeyeceğini ve birlikte yönetilmeyen 
doğal varlıklara müşterek denilmeyeceğini savunurlar (Mies ve diğ., 1988). Müşterekler, toplulukların/toplumların eylemleri ve sorumluluk bilincinin ürünleridir. Bu sebepten bir topluluktan/toplumdan bahsetmeden müştereklerden bahsetmek mümkün değildir (Sato ve Alarcon, 2019).

Müştereklerin biyofiziksel kaynakların ötesinde, bilgi ve sosyal formları içermesi (soyut müşterekler) ekofeminist araştırmacılar için önemlidir. Bu doğrultuda, toplumsal yeniden üretim sürecinde müşterekleştirme pratikleri ile (ör. çocuk bakımı, yaşlı bakımı, ev işleri) kolektif alternatifler üretilebileceğini savunurlar (Sato ve Alarcon, 2019).

Müşterekler, “dönüştürücü politikalar” tartışması içinde önemli bir role sahiptir. Ekofeminist literatürde müşterek alanların çitlenmesini engellemek ve halihazırda çitlenmiş olanları geri kazanmak üzere dönüştürücü politikalar üretilmesi için "kolektif eylemlilik üzerinden mülkiyet" ve "toplumsal yeniden üretim üzerinden mülkiyet" tartışmaları öne çıkmaktadır. Süreçlerin sonuçlardan daha önemli olduğunu savunan post-yapısalcı görüşlere göre, toplumsal cinsiyetleştirme (gendering) ve müşterekleştirme (commoning) kavramları bu doğrultuda tartışılması daha uygun kavramlardır (Sato ve Alarcon, 2019).

Post-kapitalist FPE yaklaşımı müşterekleştirme pratiklerinin bir süreç olarak ele alınması ve her mülkiyete uygulanabilmesi için üç temel anlayış önermiştir; (I) Müştereklerin ve topluluğun (yeniden) birlikte üretimi ve çitlenmiş alanların (yeniden) müşterekleştirilmesi, (2) Özel mülkiyet, kamu mülkiyeti ya da açık erişim fark etmeksizin her türlü mülkiyet üzerinde müşterekleştirme pratiklerinin ele alınması ve yeni müşterekler oluşturulması, (3) Yönetilmeyen doğal varlıkların henüz çitlenmeden önce müşterekleştirilmesi. Bunlara ek olarak, atıklar gibi gezegene zarar veren olumsuz müştereklere dair sorumluluk alınması ve harekete geçilmesi (Sato ve Alarcon, 2019).

Nightingale (2019), müşterekleştirme pratiklerini sosyo-doğal süreçler olarak tariflemektedir. Sosyo-doğal süreçler, eleştirel sosyal bilimlerde "insanmerkezci olmayan sosyo-ekolojik sistemler" olarak tariflenebilir (Castree ve Braun, 1998). Sosyodoğal süreçler, toplulukları ekoloji içerisinde tariflemekte ve sosyal ile doğal olanı birlikte sınıflandırılmaktadır. Nightingale (2019), müşterekleştirme ilişkilerinin kesişimsel olduğunu ve topluluktaki bireylerin güç ilişkilerine göre sosyal ilişkilerin ve müşterekleştirme pratiklerinin değişiklik gösterdiğini vurgulamaktadır. Bu bağlamda, müşterekleştirme pratikleri sosyodoğal içselleştirmeleri ve dışsallaştırmaları içeren, bu yüzden dışarıyı/ötekiyi, diğerini zorunlu kılan bir güç hareketi olarak tariflenmektedir (Nightingale, 2019).

Bugün dünyada müştereklerin kolektif yönetimi, kent bahçeleri, boş parsel işgalleri, gerilla bahçeleri, açık kaynak ve internet temelli üretim çabaları, alternatif para birimleri (ör. kripto/ sanal para) vb. müşterekleştirme pratikleri devam etmektedir (Bollier ve Helfrich, 20I5). Müşterekleştirme, varlığı ve kalıcılığı sürekli olarak yeniden müşterekleştirme pratiklerinin uygulanmasına bağlı olan parçacıl ve geçici bir durumdur. Sosyo-doğal ilişkilerin oluşturduğu öznellikler, müştereklere duygusal bağlılığa sebep olan ilişkileri ve gündelik yaşam pratiklerini oluşturmaktadır. Bu bağlamda, çevre hareketlerine katılan sosyo-doğal topluluklar, güç çatışmalarının üstesinden gelememekte, aksine bu çatışmaların parçası olmaktadır. Müşterekleştirme pratiklerinin sonucu ise sıklıkla beklenmedik, kendiliğinden ve şaşırtıcı olmaktadır (Nightingale, 2019).

Shiva (1992), Hindistan'daki kadın çiftçi örneklerinden yola çıkarak geleneksel tarım, hayvancılık ve ormancılık uygulamalarında kadın emeğinin nasıl örtük kaldığına dikkat çekmektedir. Kapitalist sistemde ücret döngüsüne girmeyen kadın emeği, bir para karşılığı olmadığı için üretken olmayan emek kategorisinde değerlendirilerek bilinçli bir şekilde görünmez kılınmaktadır. Kadınların üretim ve toplumsal yeniden üretim sürecinde doğaya ve biyoçeşitliliğe zarar vermeden, hatta bizzat biyoçeşitliliği sürdürülebilir kılarak harcamış olduğu emek-zaman, doğanın "kendiliğinden” üretkenliğinin bir parçası olarak kabul edilmektedir. Oysa tohumların çeşitliliği ve sürekliliği, gıda döngüsü, hayvan yemi, ormancılık, üretip satılan ya da gündelik tüketilen ürünler yerli kadınların bilgeliği ve çalışkanlığıyla meydana gelen süreçlerdir. Özellikle az gelişmiş ve gelişmekte olan ülkelerde kendi kendini idame ettirmenin tek yolu yerel tohum üretmek ve çeşitliliği sağlamaktır. Tohumlar dışarıdan satın alınmaya başlandığında ise kadınlar üretimde karar verici konumlarını kaybetmekte, niteliksiz işgücü ve tüketici konumuna indirgenmektedir. Gizli hasat olarak tariflenen yabani ya da yardımcı bitkiler, çoğu zaman müşterek arazilerden toplanmaktadır. Depolarda, tohumluklarda saklanan bu gizli hasat, kadınların sorumluluğundadır ve ihtiyaç zamanlarında ortaya çıkarılır (Rocheleau, 1995; Zweifel, 1997; Howard, 2003; Deda ve Rubian, 2004).

FAO (2004) raporuna göre savaş, hastalıklar, yeni iş sahaları için kırdan kente göç vb. sebeplerle kırsaldaki erkek nüfusunun azalması sonucunda kadınların kırsalda üretime dair sorumlulukları artmakta ve "tarımın dişileşmesi” olarak tarif edilen bir olgu ortaya çıkmaktadır (Deda ve Rubian, 2004). Ancak özellikle az gelişmiş ülkelerde mülkiyet sahipliğindeki cinsiyet eşitsizliği, kadınların doğal varlıklara erişimini gittikçe zorlaştırmaktadır. Toplumsal cinsiyet eşitsizliği ve buna bağlı olarak doğal varlıklar ve/veya ekolojik müştereklere erişim ve karar verme süreçlerindeki eşitsizlik ortadan kaldırılmadığı sürece biyoçeşitliliğin gerçek anlamda korunabileceğini söylemek mümkün değildir (Rocheleau, 1995; Howard, 2003). Kadınların kırsaldaki yerel örtük bilgisinin önemi güncel çalışmalarda gittikçe daha görünür hale gelmektedir. Bu bağlamda, yerel örtük bilgiyi tanımak, özümsemek ve bu bilgiyi bilimsel bilgiyle geliştirmek gereklidir. 


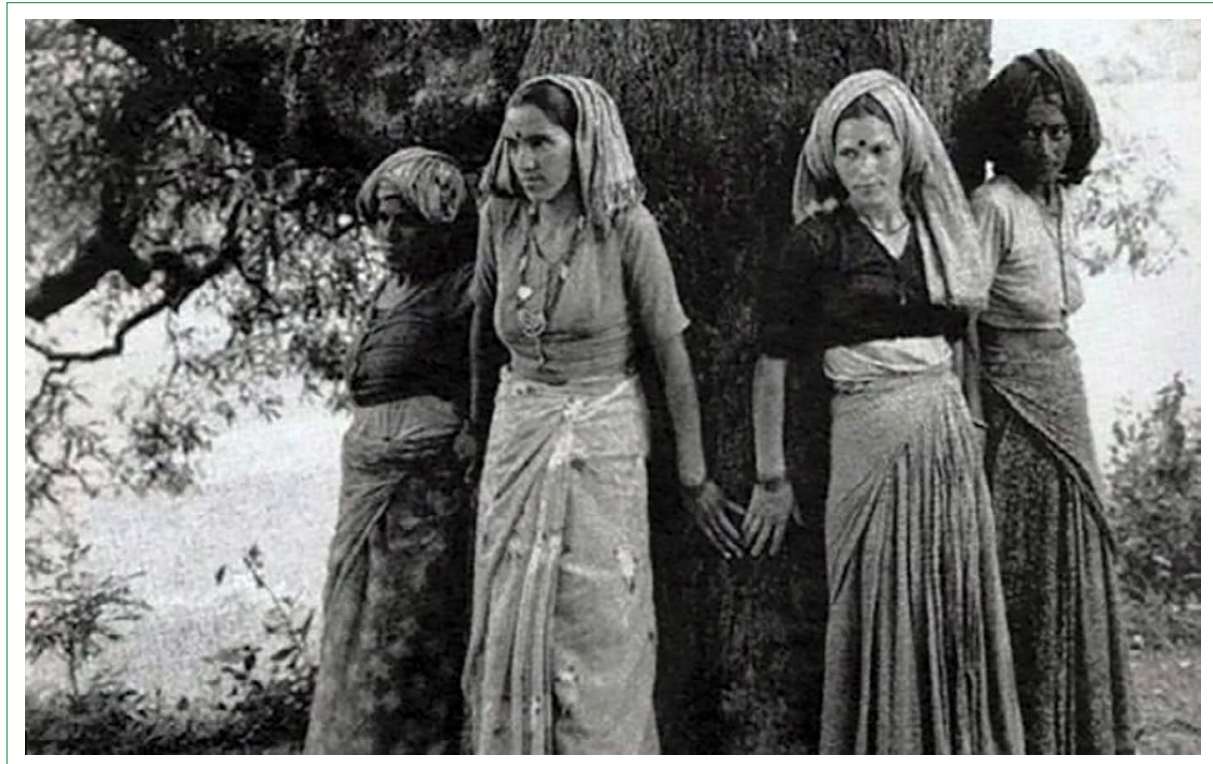

Şekil I. Hindistan Chipko Hareketi, 1970 (Url-I)

\section{Ekofeminist Literatürde Çevre Hareketleri}

Doğal varlıkların ve/veya ekolojik müştereklerin çitlenmesine karşı tepki olarak ortaya çıkan çevre hareketlerinin, 17. ve 19. yüzyıllar arasında yerel toplulukların (ör. kızılderililer, aborjinler) direnişleriyle başladığı kabul edilmektedir (Garner, 1996). Çevre hareketlerinin başından itibaren kadınlar da yaşam alanlarını savunmak için halk aktivizminin içine çekilmek zorunda kalmıştır. Tarımda makineleşme ile birlikte ortaya çıkan Yeşil Devrim, kırsal alandaki cinsiyet rolleri üzerinde etkili olmuştur. Geleneksel yöntemler ikameci makineleşmiş tarım, çoğunlukla kadınlara emek yoğun, düşük ücretli ve güvencesiz çalışmak zorunda kalacakları istihdam alanları yaratmış ve iş yükünü artırmıştır. Toplumsal normlara göre oluşan cinsiyet rolleri, sınıf farklılıkları, ırk ve etnik köken de sıklıkla kadınların aleyhine kullanılmaktadır. Erkeklerin bürokratik kurumlardaki pozisyonları doldurmaları da kadınların sesinin daha az duyulmasına sebep olmaktadır. Bu sebeple, kadınların örgütlediği çevre hareketlerinin tarih boyunca kendiliğinden ve gayri resmi biçimde ortaya çıktığı söylenebilir (Deda ve Rubian, 2004).

Çevre hareketleri ve kadınların bu hareketlerdeki rolü incelendiğinde, kadınlar tarafından liderlik edilen ve çevreciliğin çehresini değiştiren iki önemli örnek görülmektedir. Bunlardan ilki Chipko Hareketi'dir. 17. yüzyılda Hindistan'da devlet destekli kerestecileri engellemek amacıyla ağaçlara sarılarak kendilerini siper eden 363 köylü, bu eylemleri sırasında öldürülmüşlerdir. Bu olaydan yaklaşık 250 yıl sonra 1970'li yıllarda bir grup köylü kadın yine kesilmesi planlanan ağaçlara kendilerini siper etmişlerdir. Chipko Hareketi olarak adlandırılan bu eylemler birkaç yıl içinde tüm Hindistan'a yayılmış ve ormancılık alanında reformların yapılmasını sağlamışır (Şekil I).
İkinci önemli örnek, Kenya Yeşil Kuşak Hareketi'dir. 1977 ylında Wangari Maathai önderliğinde Kenya'da başlayan hareket kapsamında çölleşmeye dikkat çekmek için 50.000 kadın 20 milyon ağaç dikmiştir ve yapılan çalışmalar bugün hala devam etmektedir (Şekil 2). Daha sonra geniş kitlelere yayılan bu hareketler, kadınların öncülüğünde başlaması sebebiyle ekofeminizmin mihenk taşları olarak kabul edilmektedir (Shiva, 1993; Breton, 1998; Deda ve Rubian, 2004; Zelezny ve Bailey, 2006). Ağaçlara sarılmanın ve fidan dikmenin bugün halen çevre aktivistlerinin en sık başvurduğu barış̧̧ıl eylem türleri arasında olduğu görülmektedir.

Chipko ve Yeşil Kuşak Hareketleri, çevre konularının yerel ve nihayetinde kontrol edilebilir olduğunu, çevre tahribatının sorumlularının sıklıkla güç erkleri olduğunu, sosyal adaletsizliğin halk aktivizmini alevlendirdiğini, etkili çözüm ve eylemlerin salt devlet kurumları ya da bürokratik hiyerarşilere bağlı olmadığını, kolektif hareketlerin (müşterekleştirme pratiklerinin) yeni sosyal normlar oluşturduğunu, azmin politika değişimi ve eğitim gerektirdiğini ve çevre hareketlerinin ortak çevre duyarlılı̆ına sahip yetkin kadınlar tarafından da başlatılabileceğini kanıtlaması açısından önemlidir (Zelezny ve Bailey, 2006).

Birinci ayrım ekofeministlerden Elin Wagner, Çalar Saat (194I) kitabında kadınları üretimin makineleşmesinin sonuçlarına karşı uyarmıştır. Tarımda makineleşmenin ve kimyasal pestisitlerin savaş ile aynı derecede ölüm üretici teknolojiler olduğunu, Rachel Carson'un çığır açan kitabı Sessiz Bahar'dan (1962) 20 yıl önce sezmiştir. Wagner, doğu İsveç'in kadim inanışlarından esinlenmiş, anaerkil anlayış ve yöntemlerinin yeniden canlandırılması ve doğayı, insanlığı ve gelecek nesilleri korumak için makineleşen tarım yerine geleneksel (organik) tarımın sürdürülmesi için çalışmalar yapmıştır. Elizabeth Tamm ile birlikte Dünya ile Barış (194I) kitabını yazmış ve 1944 yı- 


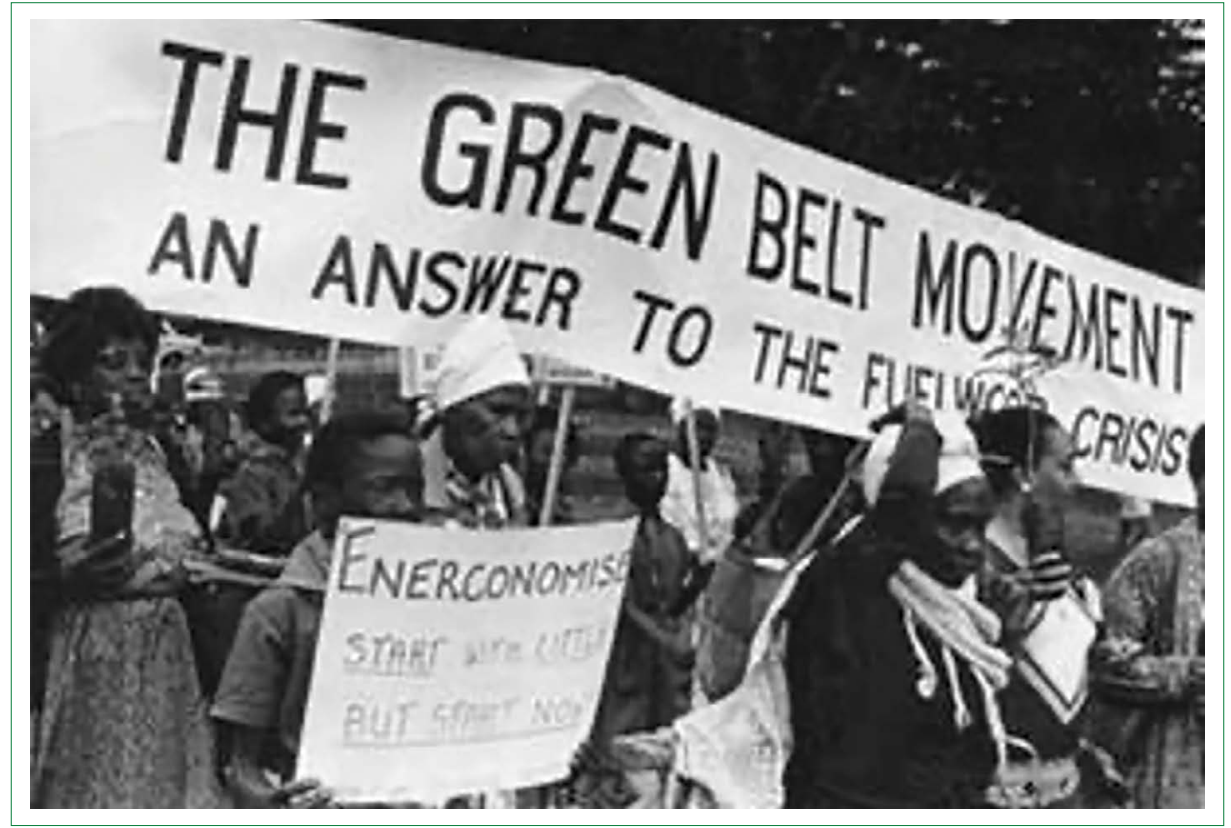

Şekil 2. Kenya Yeşil Kuşak Hareketi, 1977 (Url-2).

lında Flory Gate ile birlikte organik tarım ve hayvancılık çiftliği kurmuştur (Peterson ve Merchant, 1986).

Wagner'den esinlenen Hermodsson (1984), etik düşünceyi bilimden ayırarak bilimsel araştırmaları sömürüye açık hale getirmesi sebebiyle pozitivist düşünce okulunu eleştirmiştir. Pozitivist yaklaşım, modern endüstri toplumunda çevrenin/ doğanın teknoloji eliyle kontrol edilmesinin önünü açmıştır. $\mathrm{Bu}$ dönemde öne çıkan ekofeministler, geleneksel anaerkil etik değerlerin modern topluma hatırlatılarak, çevrenin/doğanın (yeniden) insan müdahalesi olmaksızın özgürleşebileceğini ileri sürmüştür. Ancak birinci ayrım ekofeministlerin, anaerkil anlayış ve yöntemlerinin yeniden canlandırılması önerisi, kadınlara politik bir eylem alanı tariflememesi bakımından eleştirilmiştir (Peterson ve Merchant, 1986).

Bu bağlamda, kadın ve çevre hareketleri, toplumsal cinsiyet rolleri, politik yararlar ve yeniden üretim politikaları kapsamında birlikte değerlendirilmelidir. Yeniden üretim politikaları incelendiğinde, erkekler için ekonomik büyümenin; kadınlar içinse ekolojik dengenin daha çok fayda getirdiği görülmektedir. Peterson ve Merchant (1986), bu politikalarını İsveçli kadın aktivistler özelinde 4 ayrımda ele almıştır: (I) ekolojik ve nükleer sorunlara odaklanan biyolojik (kuşaklar arası) yeniden üretim; (2) gıda güvenliği ve pestisitlere odaklanan aile (kuşak içi) yeniden üretim; (3) çocuk ve yaşlı bakımı gibi geleneksel toplumsal yeniden üretim faaliyetlerini devlete devrederek kadınların işgücüne katılımına odaklanan refah devleti (kamu sektöründe kuşak içi yeniden üretim); (4) toplumsal cinsiyet eşitliğine dayalı iş bölümüne odaklanan yeniden üretim işçisi kadınların özgürleşmesi.
Birinci ayrıma örnek olarak, I 980 yılında İsveç'te yapılan ulusal nükleer enerji referandumu verilebilir. Referandum sonucunda kadınların \%43'ünün, erkeklerinse \%2l'inin nükleer enerjiye hayır oyu vermesi dikkat çekicidir. İkinci ayrıma örnek olarak, tarım ilaçlarına karşı kadınların başını çektiği sayısız ulusal protesto verilebilir. Bunlara ek olarak, Peterson ve Merchant (1986) İsveç'te süregelen çevre hareketleri kapsamında ideolojilerini cinsiyet ayrımına göre temellendiren (birinci ayrım) ve temellendirmeyen (ikinci ayrım) ekofeministlerin, çevre dernekleri yönetiminde ve çevre hareketlerinde aktif rol aldığını tespit etmiştir (Peterson ve Merchant, 1986).

Kadınların çevre hareketlerindeki aktif rolüne dair bir diğer örnek ise, 1980'li ve 90'lı yıllarda ABD'de endüstriyel zehirli atıklara karşı yapılan halk protestolarıdır. Krauss (1993), çevre hareketlerinde aktif olan kadınları farklı ırk, sınıf ve etnik grupların perspektifinden kesişimsel olarak ele almıştır. Protestolara katılan kadın çevre aktivistlerinin kaygıları temelde çevre adaleti, aile ve toplum sağlığı bağlamlarında ele alınmıştır. Özellikle mavi yakalı işçi kadınlar, çocuk hastalıklarının, çoklu düşüklerin, doğuştan engelli bebeklerin, kanser kaynaklı ölümlerin ve diğer risklerin zehirle bağlantısını deneyimleyerek öğrenmişler ve çevre konularında teknik bilgileri olmasa bile, gelecek nesiller için duydukları kaygı sebebiyle çevre hareketlerinin ön saflarında yer almışlardır (Krauss, 1993). Gerçek bir hikâyeden uyarlanan Erin Brockovich (2000) filmi de 1990'lı yıllarda ABD'de endüstriyel zehirli atıklara karşı verilen hukuk mücadeleleri içinde kadınların rolünü anlatması bakımından önemli bir örnektir.

Ekofeminist çalışmalardaki çeşitli anket ve saha araştırması bulguları, kadınların ekolojik krizlere ve çevre korumaya yö- 
nelik eylemlere erkeklerden daha duyarlı olduklarını kanıtlar niteliktedir. Cinsiyetçi sosyal roller, ekonomi-çevre/doğa takaslarında, çevreye duyarlı eylemlere katılımda (ör. çöpleri ayrıştırmak), çevreye duyarlı tutum ve ekolojik dünya görüşünde, çevre sorunlarını ciddiye almakta, çevre politikaları tercihlerinde ve çevre kirliliği gibi aileyi ve toplumu etkileyebilecek yerel sağlık problemlerinde farklılaşmaktadır. Kadınların hava ve su kirliliği gibi sağlığı etkileyen çevre problemleri söz konusu olduğunda erkeklerden daha çok kaygı duyduğu görülmektedir. Aynı durum küresel ısınma ve biyoçeşitlilik kaybı gibi küresel çevre problemleri için de geçerlidir. McCright ve Xiao (20।4), atık geri dönüşümü, su kullanımı azaltımı gibi çevreye duyarlı özel eylemlerde kadınların daha aktif olduğunun; ancak imza kampanyası ve çevre hareketleri gibi kamusal eylemlerde anlamlı bir cinsiyet ayrımının yapılmadığının altını çizmektedir (McCright ve Xiao, 20I4).

Toplumsal cinsiyet ve çevrecilik söz konusu olduğunda, kadınların çevre örgütlerinde diğer politik sahalara göre daha görünür olduğu söylenebilir. Ancak, kadınların çevre hareketleri içerisinde daha aktif olduklarına ilişkin yeterli bütüncül veri bulunmamaktadır. Çevre örgütlerinde ve çevre hareketlerinde aktif olma durumu birçok değişene tabidir. Ücretli iş, ev işi, çocuk bakımı gibi toplumsal üretim ve yeniden üretim sürecinde kadınların görünür ve görünmez emeklerinden arta kalan kısıtlı zamanın ne kadarını çevre hareketlerine ayırabileceği tartışma konusudur. Çevre sosyolojisi ve ekofeminist teori birçok sosyo-kültürel, yapısal ve biyolojik sebepten ötürü çevre konusunda kadınların erkeklerden daha aktif olduğunu kabul etmektedir. Öte yandan, toplumsal hareketler yazını birçok demografik faktör sonucunda kadınların çevre hareketlerine katılımının erkeklerden daha zor olduğunu ifade etmektedir. Bu bağlamda, kadınların toplumsal üretim ve yeniden üretim süreçlerindeki rolleri sonucu oluşan zaman kısıtı sebebiyle çevre hareketlerindeki görünürlüğüne eleştirel bir perspektiften yaklaşılması gerekmektedir (Tindall ve diğ., 2003).

Mohai (1992) çalışmasında, kadınların özel alanlarında çevre dostu aktivitelerinin daha fazla olmasına rağmen, kamusal organize aktivizm içinde erkekler kadar görünür olmadığını tespit etmiştir. Tindall ve diğerleri (2003), kadınların çevre dostu aktivitelerinin aktivizme dönüşmemesini biyografik uygunluk durumu ile ilişkilendirmektedir. Biyografik uygunluk durumu, sosyo-ekonomik ve demografik faktörler, toplumsal cinsiyet eşitsizliği ve toplumsal cinsiyete dayalı iş bölümü gibi değişkenlerle farklılaşmaktadır. Dolayısıyla, çoğu ülkede kadınların erkeklerden daha düşük ücret alması, ev işi, çocuk bakımı gibi ücret döngüsüne girmeyen (görünmez) işlerin tam zamanlı bir meşguliyet durumu yaratması vb. sebebiyle kadınların biyografik uygunluğu azalmaktadır. Bu durum, kadınların çevre dostu aktivitelerinin (ör. toplu taşım kullanma, geri dönüşüm) görünür bir aktivizme dönüşmemesinin başlıca sebebidir (Tindall ve diğ., 2003).
Zelezny ve Bailey (2006), modern çevreciliğin mevcut ekolojik krizlere yanıt olamadığı eleştirisine karşın literatürde yeni bir model önermektedir: üçüncü dalga çevrecilik modeli. Bu modelde, kadınların üçüncü dalga çevrecilik modeli içerisinde lider pozisyonda olmaları ve sürdürülebilir çevre hareketlerinin kadınlar tarafından organize edilmesi gerekliliği savunulmaktadır.

Türkiye'de özellikle son 10 yılda, farklı alanlarda mücadele eden sınıf, kadın ve çevre hareketlerinin birlikte hareket etmeye başlaması; neoliberal politikalar sonucunda ortaya çıkan işsiz ve güvencesiz kesimin, ekolojik yıkım mağdurlarının, gelecek kaygısı duyan gençlerin, kazanılmış hakları gasp edilenlerin, kentsel dönüşüm mağdurlarının, göçmenlerin, mültecilerin ve köylülerin bu toplumsal hareketler ekseninde ortaklaşması dikkat çekicidir. Bu ortaklaşmalar yerel direnişler ya da ülkesel sosyal patlamalar şeklinde iki biçimde kendini göstermektedir (Çetinkaya, 2008).

Yapılan çalışma, çevre hareketlerini müşterekleştirme pratikleri olarak ele almakta ve çevre hareketleri özelinde Türkiye'de 2009-2019 yılları arasında gerçekleşen eylemler ve direnişleri ekofeminizm ve müşterekler perspektiflerinden incelemektedir. Bu bağlamda, örneğin çevre hareketleri, Emek Sineması için yapılan eylemler, LGBTil+ eylemleri ya da Sulukule için yapılan eylemlerin tümü müşterekleştirme pratikleri olarak toplumsal hareketler içerisinde birlikte değerlendirilebilir. Gündelik yaşamın, her alanındaki çitleme hareketlerine karşı ortak reaktif bir eylem kültürü oluştuğu ve bu eylemlerin tümünün müşterekleştirme pratikleri olarak ortaklaştığı söylenebilir.

\section{Ekofeminist Perspektiften Türkiye'de Çevre Hareketleri}

Türkiye'deki çevre hareketlerine bakıldığında sıklıkla yerel doğal ve ekonomik varlıklara doğrudan zarar veren uygulamalara karşı yerelde direnişlere rastlanmaktadır. Diğer birçok toplumda/toplulukta olduğu gibi, Türkiye'de de doğal varlıklar ve kırsal üreticiler arasında yakın bir ilişki vardır. Buna ek olarak, Türkiye'deki çevre aktivistleri sıklıkla çevre sorunları, yeşil tüketim ve sürdürülebilirlik konularındaki endişelerini dile getirmektedir (Seçkin, 2016).

Türkiye'deki çevre hareketlerinin öncülü, 1990'lı yılların önemli gündemlerinden biri olan Bergama altın madeni direnişidir. Bergama'da siyanürle altın aranmasına karşı çıkan yerel halk tarafından yapılan eylemler ve hukuki mücadeleler sayesinde Türkiye çevre hukukunda emsal birçok kazanım olmasına rağmen, maden halen kapatılmamıştır (Şekil 3). Bergama direnişini takiben Kuşadası'nda ormanlık alanlar ve yerleşim yerlerinin yakınına yapılması planlanan çöp deponi alanlarına karşı verilen mücadeleler ortaya çıkmıştır. Doğayı ve yaşam alanlarını korumak için önce Ege bölgesinde yükselmeye başlayan tepkiler, yıllar içinde Türkiye'nin diğer bölgelerinde de karşılık bulmaya başlamıştır. 


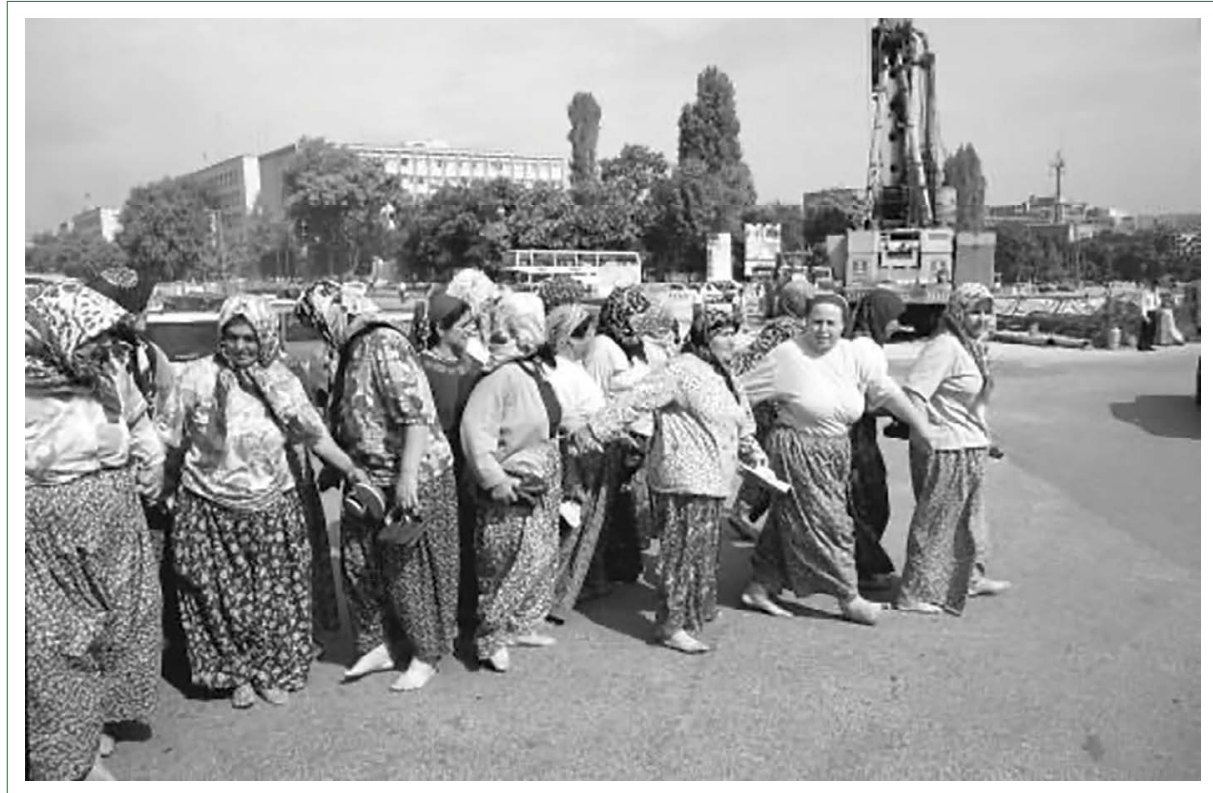

Şekil 3. Bergama altın madeni direnişi, 1992 (Url-3).

Dünyadaki diğer birçok toplumda/toplulukta olduğu gibi Türkiye'de de kadınların doğa ile yakın bir ilişkisi; yeşil tüketim ve sürdürülebilirlik için önemli bir rolü bulunmaktadır. Kadınların çevre hareketlerine katılım motivasyonlarının kırsal ve kentsel alanlarda farklılık gösterdiği görülmektedir. Kentsel alanda yaşayan kadınlar çevresel yıkıma karşı yaşam biçimlerini korumaya çalışırken, kırsal alanda yaşayan kadınlar yaşam alanları için mücadele vermektedir. Türkiye'de çevre aktivisti kadınlar çevre problemleri ile ilgili endişelerini dile getirirken doğa ve kadın ilişkisini vurgulamaktadırlar; ancak, henüz ekofeminist bir hareketin var olduğu söylenemez (Seçkin, 2016).

Ekofeminist literatür kapsamında yayımlanmış ilk Türkçe kitap, Emet Değirmenci editörlüğündeki makale derlemelerinden oluşan ve Türkiye kırsalındaki kadınların yerel örtük bilgilerinden dikkat çekici örnekler sunan Kadınlar Ekolojik Dönüşümde (20I0) kitabıdır. Bu çalışmalarda, özellikle tohum, tıbbi aromatik bitkiler ve gıda güvenliği konularında kadın, tarımın belleği olarak tariflenmekte, yerel odaklı örgütler, birlikler, gruplar, dernekler ve kooperatifler aracılığıyla (yeniden) teşvik edilen yerel tohum üretimi ve kırsal kalkınma örneklerine odaklanılmaktadır (Değirmenci, 2010).

Yapılan saha çalışmalarında, özellikle kalkınmacı dönemde tarımda makineleşme ile birlikte kadınlar ve erkekler arasında artan mülkiyet eşitsizliği, özel ve kamusal alanlarda artan cinsiyetçi kullanımlar ve buna paralel karar verme süreçlerine katılımı kısıtlanan kırsaldaki kadınların varlığı tespit edilmiştir. Sonuç olarak kadınlar, geçimlik üretim, ticari üretim ve hanenin yeniden üretiminden sorumlu olarak birden fazla işte çalışmalarına rağmen, yeterince ücret alamamakta, mülk edinememekte, kredi çekememekte ve karar verme süreçlerine katılamamaktadır. Marshall Projesi, Yeşil Devrim ve GAP gibi neoliberalleşme projelerinin kırsal alanlarda toplumsal cinsiyet eşitsizliğini daha da derinleştirdiği söylenebilir (Yüksekkaya, 20l8).

Shiva ve Mies tarafından yazılan ve 2018 yılında Türkçe'ye çevrilen Ekofeminizm (1993) kitabının Türkiye'de biyoçeşitlilik, kadınlar ve çevre hareketleri bağlamında yapılan çalışmaları artırmada etkili olduğu/olacağı düşünülmektedir (Shiva ve Mies, 1993). Ayrıca, 2003 yılı itibariyle toplumsal cinsiyet ve ekofeminist perspektiften çevre hareketleri ve sürdürülebilir kalkınmayı inceleyen, Kamu Yönetimi, Sosyoloji, Felsefe, Uluslararası İlişkiler ve Hukuk bölümlerinde yazılmış II adet tez çalışması tespit edilmiştir (Ulusal Tez Merkezi, 2020). Ancak, ekofeminist literatüre ve kadınların çevre hareketlerindeki yerine dair Türkçe kaynakların henüz çok kısıtlı olduğu görülmektedir.

Türkiye'de yapılan ekofeminist çalışmalara bakıldığında, çalışmanın bulgularıyla da örtüşen biçimde, kadınların ve çocukların çevre eylemlerinde önemli bir rolü olduğunu görülmektedir (Berkay, 2010; Kadirbeyoglu, 2010; Seckin, 2016; Turk, 20।8; Hazar, 2020). Yapılan çalışmalar, kırsal alandaki kadınların çitleme hareketlerine karşı en kırılgan grup olduğunu; ancak bu kadınların eylemler süresince sıklıkla "vitrin" olarak kullanılarak, "erkek egemen" çevre derneklerinin karar alma süreçlerinde yeterince temsil edilmediklerini ortaya koymaktadır. Hatta bu sebeple, KOSKA (Kuzey Ormanları Savunması Kadınları) gibi karar alma süreçlerinde kadınları güçlendirmeyi amaçlayan alternatif oluşumlar ortaya çıkmıştır (Türk, 20I8). 


\section{Yöntem ve Bulgular}

Yapılan çalışma, ekofeminizm ve müşterekler literatürleri kapsamında Türkiye'de ekolojik müştereklerin çitlenmesi ekseninde ortaya çıkan çevre hareketlerini ve bu hareketler içerisinde kadınların yerini incelemektedir. Medya içerik analizi yöntemi kullanılan çalışmanın ilk aşamasında, ekofeminizm, müşterekler ve çevre hareketleri kavramlarına dair literatür taraması yapılmıştır. Çalışmanın ikinci aşamasında, 2009-20।9 yılları arasında Türkiye'de basına yansıyan çevre hareketleri ve bu hareketlerdeki kadınların görünürlüğü içerik analiziyle değerlendirilmiştir. Çalışmanın son aşamasında, medya analizinde tespit edilen çevre hareketleri Coğrafi Bilgi Sistemleri (CBS) analiz araçları kullanılarak haritalandırılmıştır.

\section{Medya Analizi}

Türkiye'de 2009-2019 yılları arasında gerçekleşen ve ulusal basına yansıyan çevre hareketleri, Medya Takip Merkezi (MTM) arşivinden "çevre eylemleri" anahtar kelimesiyle aratılmış ve içerik analiziyle değerlendirilmiştir (MTM, 2020). Medya analizinde tespit edilen çevre hareketlerinde kadınların görünürlüğü incelenmiş ve Coğrafi Bilgi Sistemleri (CBS) analiz araçları kullanılarak Türkiye'deki çevre hareketleri haritalandırılmıştır.

İçerik analizi bulgularına göre, Türkiye'de son on yılda toplamda $\mathbf{1 5}$ konuda $\mathbf{7 0 0}$ çevre hareketi tespit edilmiştir. Çevre hareketleri konularına göre yoğunluk sırasıyla; çevre tahribatı, çevre kirliliği, hidroelektrik santrali (HES), taş ocağı, termik santral, maden, iklim değişikliği, nükleer santral, jeotermal enerji santrali (JES), balık çiftliği, rüzgâr enerji santrali (RES), hayvan hakları, biyogaz enerji santrali (BES), baz istasyonu ve genetiği değiştirilmiş organizmalar (GDO) ile ilgilidir (Şekil 4).

Buna göre, 2009-20I9 yılları arasında Türkiye'de; 147 çevre tahribatı, 108 çevre kirliliği, 86 HES, 65 taş ocağı, 60 termik santral, 59 maden, $47 \mathrm{iklim}$ değişikliği, 45 nükleer santral, 19 balık çiftliği, 19 JES, 17 RES, 17 hayvan hakları, 5 BES, 3 baz istasyonu ve 3 GDO konulu çevre hareketi tespit edilmiştir. Bu süreçte Türkiye'de yapılan ilk 5 çevre hareketi konusu; çevre tahribatı, çevre kirliliği, HES, taş ocağı ve termik santral'dir. Türkiye'de çevre hareketi yapılan ilk 5 şehir ise sırasıyla; İzmir, İstanbul, Muğla, Antalya ve Ankara'dır.

Türkiye'de çevre hareketlerinin yıllara göre sayısal değişimine bakıldığında, 20I3-20I5 yılları arasında çevre hareketlerinde bir yükseliş olduğu görülmektedir. Bu durumun 2013'te meydana gelen Gezi Parkı protestoları paralelinde ulusal ve uluslararası boyutta artan eylem kültürü ve bu eylemlerin sosyal medya aracılığıyla geniş kitlelere ulaşması ile ilgili olduğu düşünülmektedir. Buna ek olarak, 2016-2018 yılları arasında çevre hareketlerinde görülen düşüşün 2016 ve sonrasındaki OHAL sürecinde eylemlerin yasaklanması

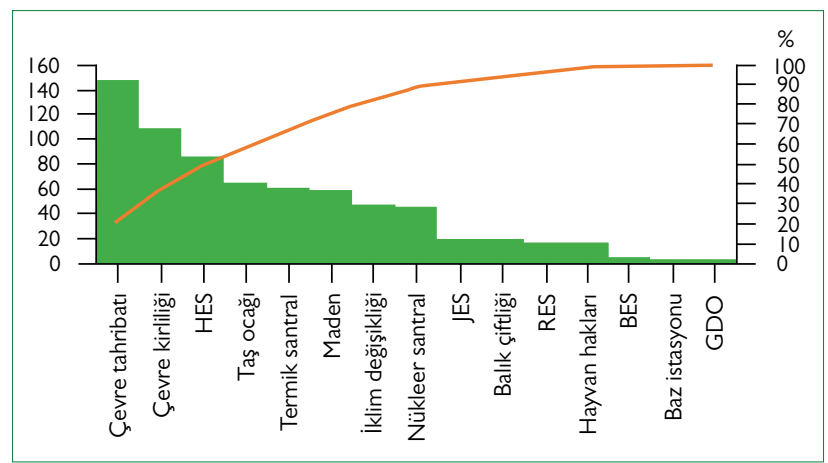

Şekil 4. Türkiye çevre hareketleri konuları (2009-2019).

HES: Hidroelektrik santrali; JES: Jeotermal enerji santrali; RES: Rüzgâr enerji santrali; BES: Biyogaz enerji santrali; GDO: Genetiği değiştirilmiş organizmalar.

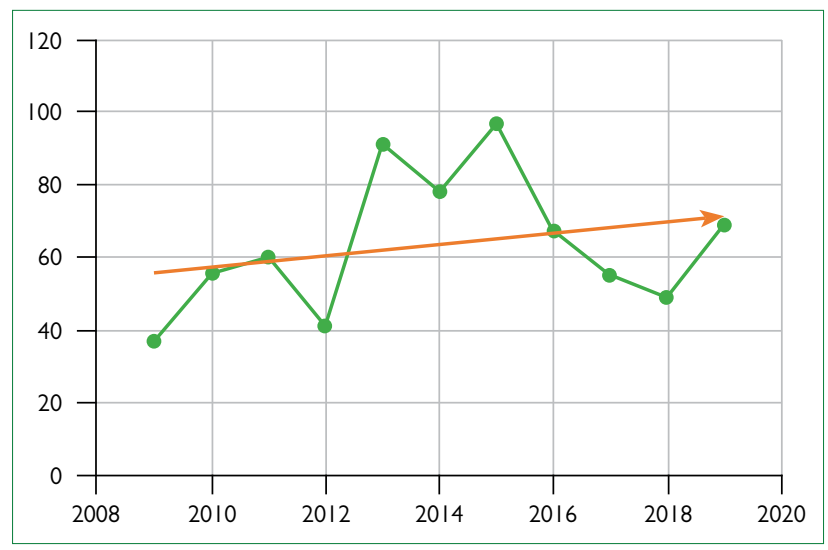

Şekil 5. Türkiye'de çevre hareketleri eğilimi (2009-2019).

sebebiyle olduğu düşünülmektedir. Türkiye'de çevre hareketlerinin 2018 yılı itibariyle yeniden yükselişe geçtiği görülmektedir. Çevre hareketleri, çevre aktivistlerinin çeşitli kazanımları (ör. Seferihisar orkinos çiftlikleri) ve kayıplarıyla birlikte (ör. Hasankeyf Ilısu barajı) bugün halen devam etmektedir (Şekil 5).

Türkiye'de gerçekleştirilen çevre hareket türleri arasında basın açıklaması yapmak, pankartlı yürüyüş yapmak, slogan atmak, ağaçlara sarılmak, fidan dikmek, dans etmek, müzik aleti çalmak, şarkı söylemek, doğa yürüyüşü yapmak, bisiklet sürmek, oturmak, yol kapatmak, tırmanmak, yere yatmak, ayakta durmak, çadır kurmak, pandomim/tiyatro gösterisi yapmak, piknik yapmak, tencere tava çalmak, tekneyle açılmak, uçuş yapmak, paraşütle atlamak, toplu telgraf çekmek, ışık açıp kapatmak, ısık çalmak, imza kampanyasına katılmak vb. çok çeşitli barışçıl eylem türleri görülmektedir.

Analizlere göre, Türkiye'deki çevre hareketlerinin öncelikle nüfus yoğunluğunun fazla olduğu metropoliten kentlerde (İzmir, İstanbul, Ankara); ardından Türkiye'nin sahil kesimlerinde yoğunlaştığı tespit edilmiştir. Bu yoğunluğun nüfus, eğitim seviyesi, çevre/doğa farkındalığı, coğrafi etmenler ve sıklıkla kıyı kentlerinde yoğunlaşan çeşitli yatırım türleri (turizm, enerji 


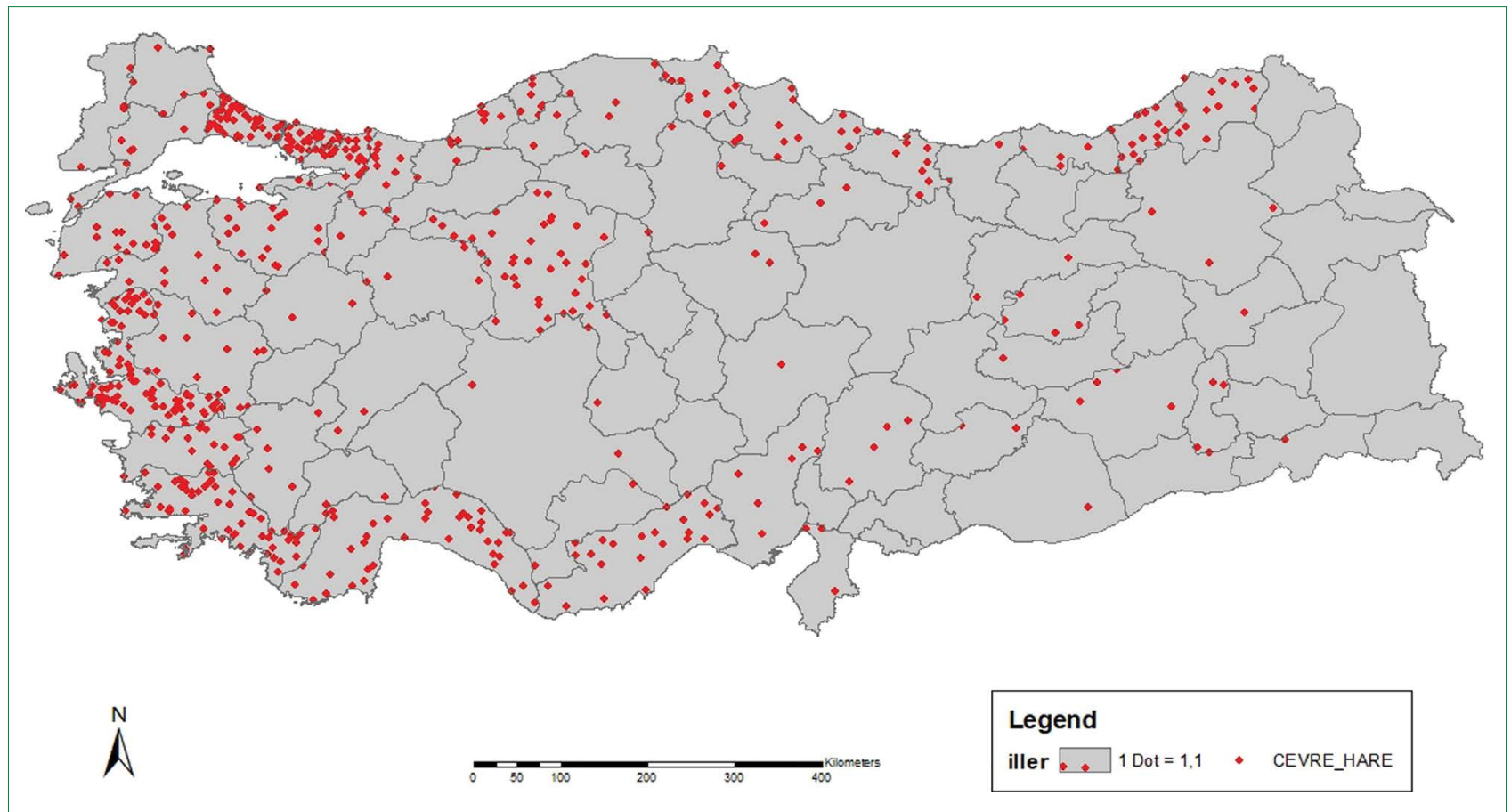

Şekil 6. Türkiye çevre hareketleri nokta yoğunluk analizi, 2009-2019.

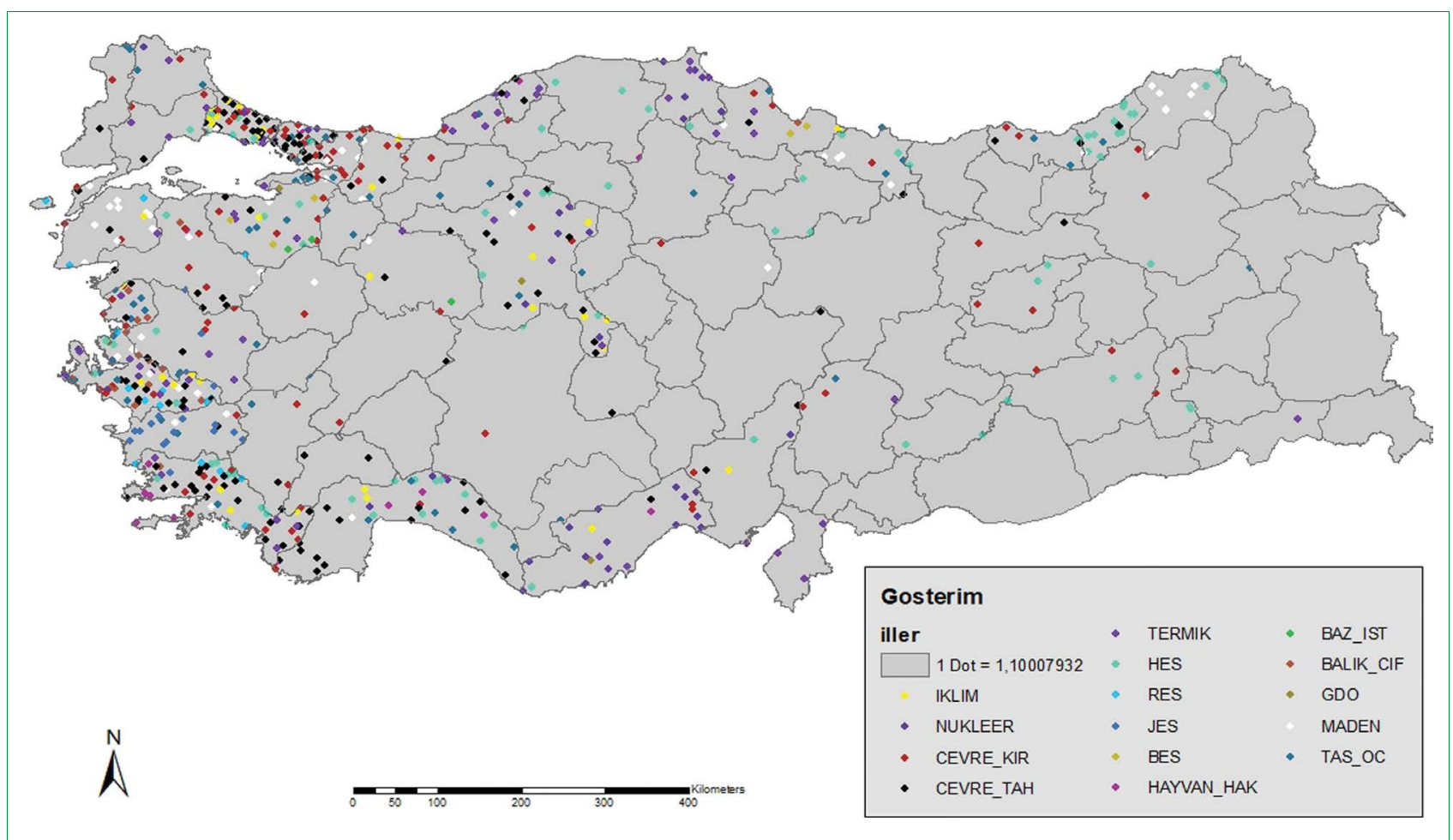

Şekil 7. Türkiye çevre hareket konuları nokta yoğunluk analizi, 2009-2019.

HES: Hidroelektrik santrali; RES: Rüzgâr enerji santrali; JES: Jeotermal enerji santrali; BES: Biyogaz enerji santrali; GDO: Genetiği değiştirilmiş organizmalar.

vb.) gibi birçok etkenle bağlantılı olduğu düşünülmektedir. Türkiye'deki çevre hareketleri yoğunluklarına ve konularına göre Şekil 6 ve 7'de mekansallaştırılmıştır.
Konumlarına göre çevre hareketlerine bakıldığında hareketlerin temelde ikiye ayrıldığı görülmektedir; (I) eylem konusunun bulunduğu bölgedeki yerel direnişler; (2) kamuoyu oluş- 
turmak için metropol şehirlerde çevre dernekleri tarafından organize edilen eylemler.

Çevre tahribatı konulu eylemler Ege Bölgesi başta olmak üzere İstanbul ve Ankara'da yoğunlaşmaktadır. Çevre kirliliği konulu eylemler, Ege kıyıları ve Marmara Bölgesinde yoğunlaşmaktadır. HES konulu eylemler, Akdeniz kıyıları ve doğu Karadeniz'de yoğunlaşmaktadır. Taş ocağı konulu eylemler, Akdeniz ve Ege kıyılarında, Marmara Bölgesinde, Karadeniz Bölgesinde ve Ankara'da yoğunlaşmaktadır. Termik santral konulu eylemler, Akdeniz ve Ege kıyılarında, batı ve orta Karadeniz'de ve Ankara'da yoğunlaşmaktadır. Maden konulu eylemler, Ege ve Marmara Bölgeleri ile doğu Karadeniz'de yoğunlaşmaktadır.

İklim değişikliği konulu eylemler, İzmir, İstanbul, Ankara başta olmak üzere Akdeniz ve Marmara Bölgelerinde yoğunlaşmaktadır. Nükleer santral konulu eylemler, Akdeniz Bölgesi, İzmir, İstanbul, Ankara ve Sinop'ta yoğunlaşmaktadır. JES konulu eylemler, Ege Bölgesinde yoğunlaşmaktadır. Balık çiftliği konulu eylemler, Ege Bölgesi başta olmak üzere, Marmara ve orta Karadeniz'de yoğunlaşmaktadır. RES konulu eylemler Ege kıyılarında yoğunlaşmaktadır. Hayvan hakları konulu eylemler, Akdeniz Bölgesi başta olmak üzere, Marmara ve orta Karadeniz'de yoğunlaşmaktadır. BES konulu eylemler, Marmara ve orta Karadeniz'de yoğunlaşmaktadır. Baz istasyonu konulu eylemler, Marmara ve İç Anadolu'da yoğunlaşmaktadır. GDO konulu eylemler, Marmara Bölgesi, Ankara ve Akdeniz Bölgesinde yoğunlaşmaktadır.

\section{Çevre Hareketlerinde Kadınların Görünürlüğü}

Türkiye'de 2009-2019 yılları arasında gerçekleştiği tespit edilen çevre hareketlerinde kadınların görünürlüğü, medya içerik analizi ile incelenmiştir (MTM, 2020). Medya analizinde tespit edilen 700 haber içerisinde $\mathbf{4 6 5}$ haberde kadınların görünür ve/veya ön planda olduğu, 169 haberde kadınların görünür olmadığı, 75 haberde ise görsel öğeye yer verilmediği tespit edilmiştir (Şekil 8).

Buna göre, kadınların 2009-2019 yılları arasında Türkiye'de gerçekleşen ve haber kupürlerinde görsel öğelerin yer aldığı $\mathbf{6 2 5}$ çevre hareketi içerisinde \%73 oranında görünür ve/veya ön planda olduğu tespit edilmiştir (Şekil 9-13).

Gelişmekte olan ülkelerin birçoğunda olduğu gibi Türkiye'de de neoliberal politikalar eliyle yeni pazar alanları ve hammadde üretmek amacıyla, doğal varlıkların ve/veya ekolojik müştereklerin çitlendiği görülmektedir. Bu süreçte çitleme hareketleri karşısında, kırsal ve kentsel alanlarda kolektif olarak yerel direnişler ve çevre dernekleri tarafından eylem konusunun yerinde ya da kamuoyunun dikkatini çekmek için büyük şehirlerde çevre hareketleri örgütlenmektedir. Çevre hareketlerine toplumsal cinsiyet ekseninde bakıldığında, müştereklerin çitlenmesine karşı ortaya çıkan direnişlerde kadınların ön planda olduğu görülmektedir.

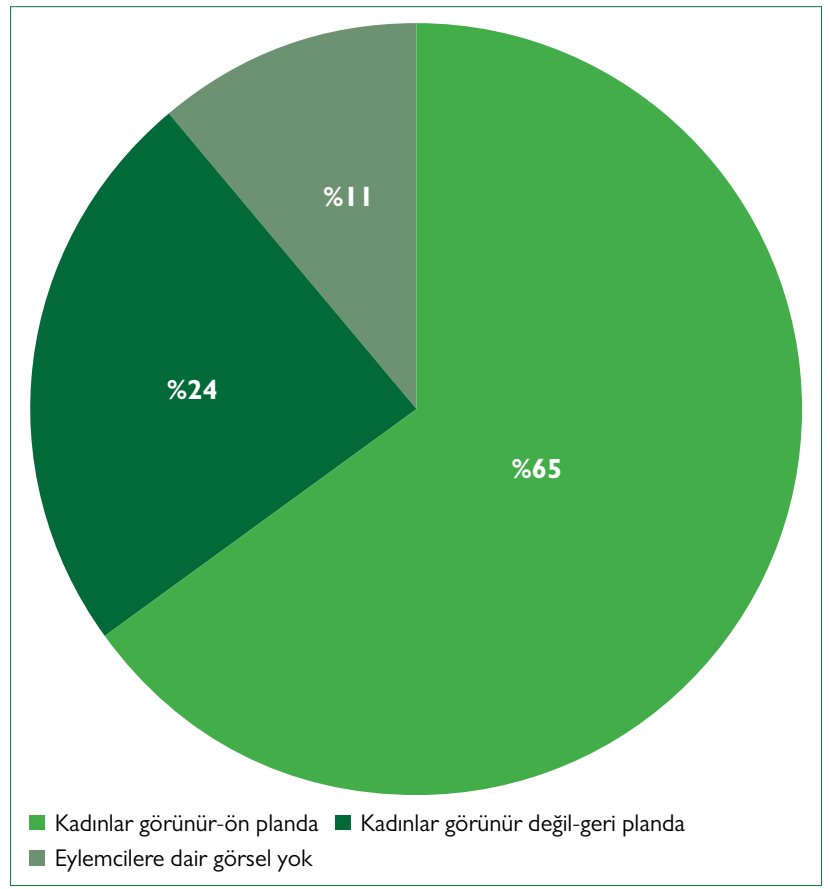

Şekil 8. Çevre hareketlerinde kadınların görünürlüğü, 2009-2019.

Bu duruma literatürde yapılan saha ve anket çalışmaları paralelinde çevre hareketlerine birinci ayrımdaki ekofeminist perspektiften bakıldığında, kadınların doğa, aile ve toplum ölçekleriyle daha güçlü duygusal bağlarının bulunması, doğal varlıklara ve kırsaldaki yaşam alanlarına dair kaygılarının daha fazla olması ve bu alanları gelecek nesillere bırakmak için daha güçlü bir istek duymaları sebebiyle olduğu yorumlanabilir. İkinci ayrımdaki ekofeminist perspektiften bakıldığında ise, çeşitli kesişimsellikler sonucunda kentsel ve kırsal alanlarda ve farklı coğrafi bölgelerde kadınların çevre hareketlerine aktivist olarak katılma süreçlerinin farklılık gösterdiği görülmektedir.

Temel ekonomik sektörün tarımsal üretim olduğu kırsal alanlarda kırsal üreticiler olarak kadınların ön saflarda olduğu görülmekle birlikte; çeşitli bölgelerde imam, muhtar ya da siyasi aktörler tarafından kahvehane, belediye, siyasi ilçe örgütü binası gibi daha eril kamusal ve/veya yarı-kamusal mekanlarda organize edilen eylemlerde kadınların görünür olmadığı tespit edilmiştir. Bu durumun biyografik uygunluk durumu (Tindall ve diğ., 2003) ile ilişkili olduğu düşünülmektedir. Bu dezavantajlara karşın, gerek kentsel ve kırsal alanlardaki çevre hareketlerinde gerekse çevre derneklerinde kadınların diğer politik sahalara göre daha aktif ve görünür olduğu dikkat çekmektedir.

\section{Sonuç ve Genel Değerlendirme}

Yapılan çalışma, Türkiye'de ekofeminizm, müşterekler ve çevre hareketlerini birlikte ele alan ilk kapsamlı araştırma olması bakımından önemlidir. Ekofeminizm ve müşterekler literatürleri, toplumsal hareketler bağlamında heterojen grupları müşterek 


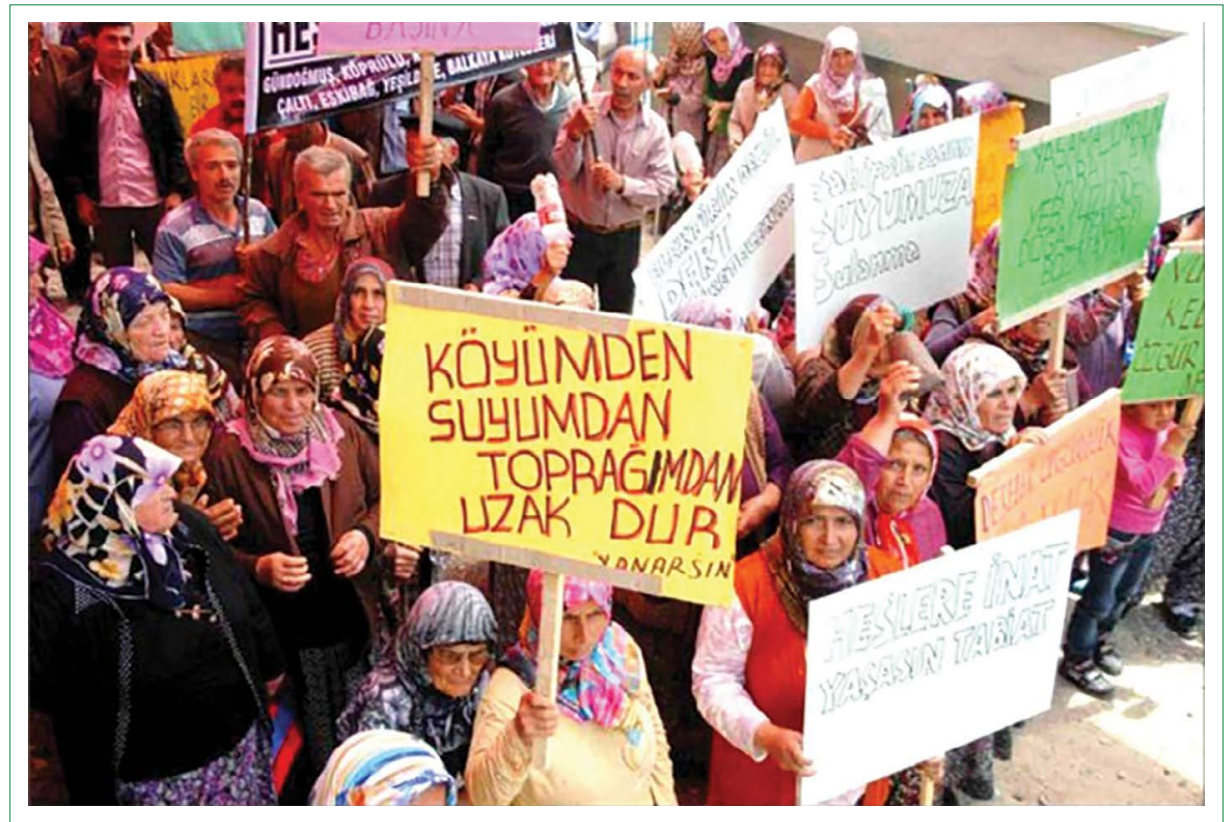

Şekil 9. Çevre hareketlerinde kadınlar, 2009-20II.

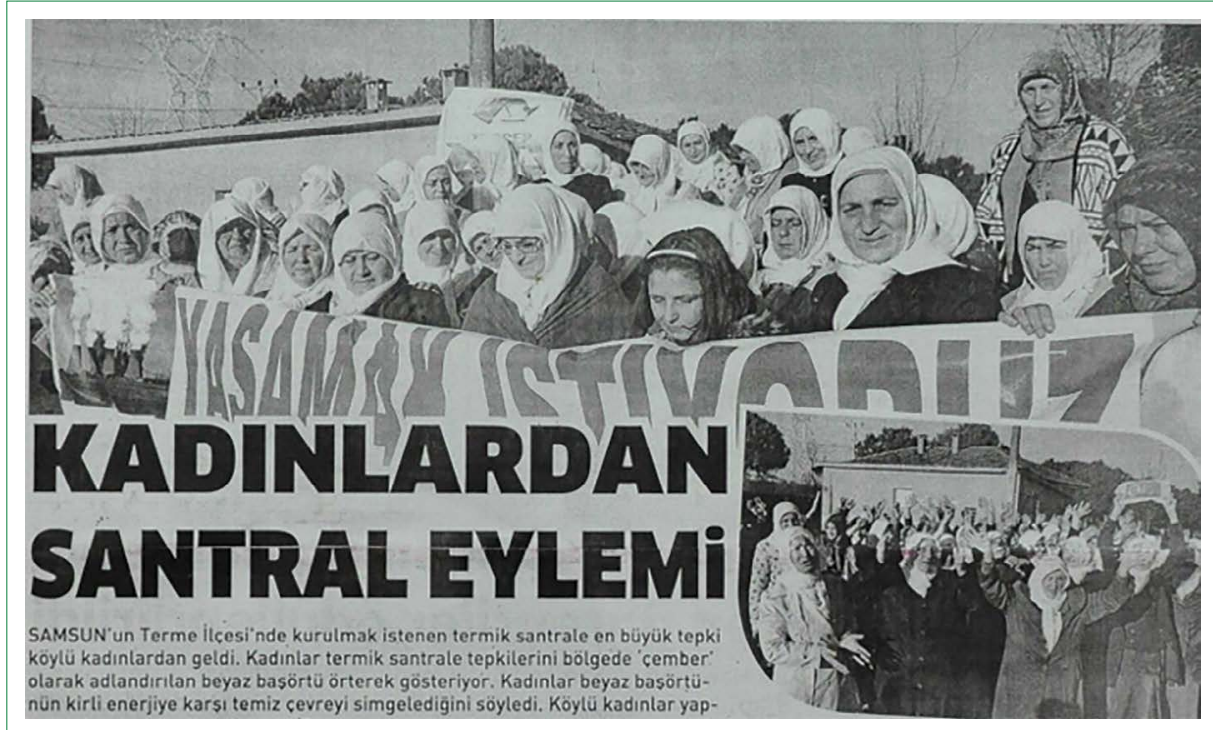

Şekil 10. Çevre hareketlerinde kadınlar, 20I2-20I4.

bir kimlik etrafında birleştirmek için yüksek potansiyele sahip olan çevre hareketlerinin biçimlerine yönelik bir teorik arka plan oluşturma potansiyeline sahiptir.

Türkiye'de gerçekleşen çevre hareketlerine toplumsal cinsiyet ekseninden bakıldığında, ekolojik müştereklerin çitlenmesi ekseninde kadın aktivistlerin ön planda olduğu görülmektedir. $\mathrm{Bu}$ durumun bir sebebinin kolluk güçlerinin ön saflardaki kadınlar ve çocuklara daha az şiddet uygulayacağının düşünülmesi olabileceği gibi, aksi durumlara da sıklıkla rastlanmaktadır. Kadınların görünür olduğu çevre hareketlerinin basında daha fazla yer bulması sebebiyle kamuoyu oluşturmak adına kadın- ların ön planda olmasının tercih edildiği de düşünülebilir. Ancak ekofeminist perspektiften bakıldığında, kadınların yaşam alanları ve gelecek nesiller için duydukları kaygıların erkeklerden daha fazla olması sebebiyle çevre hareketlerinde inisiyatif aldıkları ve kendiliğinden ön planda oldukları değerlendirmesi de yapılabilir. Bu kapsamda daha kesin çıkarımlar yapılabilmesi için, ikinci ayrımdaki kesişimsellikler bağlamında detaylı saha çalışmaları yapılmalıdır.

Türkiye'de gerçekleşen çevre hareketleri konularına bakıldığında, nükleer ve termik santrallere karşı yapılan eylemler, bir deprem ülkesi olan Türkiye'deki enerji politikalarının, ciddi 


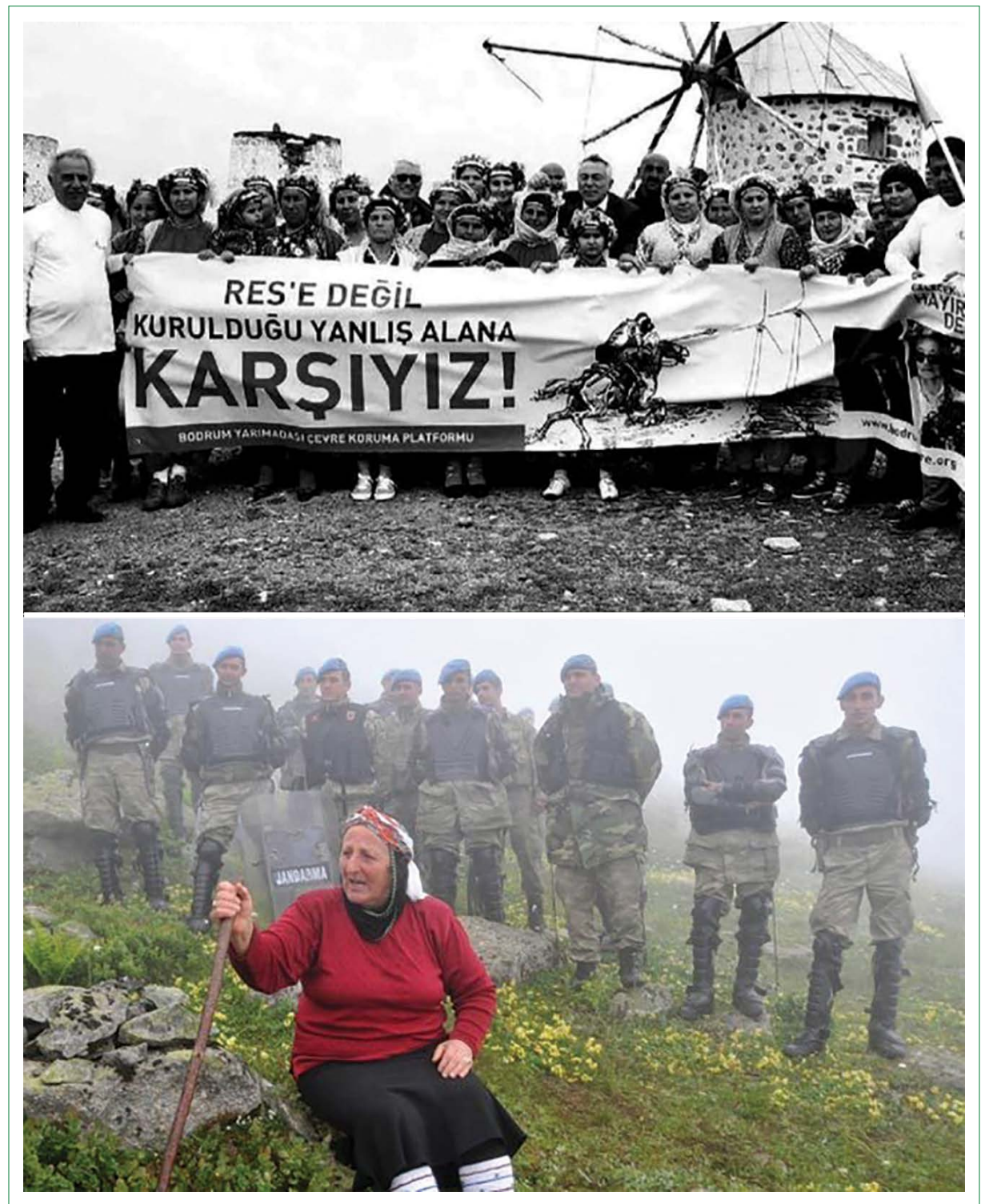

Şekil II. Çevre hareketlerinde kadınlar, 2014-2016.

risk barındıran ve birçok ülkenin kullanımından vazgeçtiği termik ve nükleer santral projeleri yerine yenilenebilir enerji kaynaklarına (rüzgâr enerjisi, güneş enerjisi vb.) yönelme ihtiyacını ve küresel ısınmaya karşı politikalara duyulan ihtiyacı ortaya koymaktadır. HES, RES, JES ve BES'e karşı yapılan eylemler, ülkenin doğal varlıklarını korumak ya da ülkenin ihtiyacının ötesinde enerji üretip diğer ülkelere satmak seçenekleri arasındaki dengenin korunması gerekliliğini ortaya koymaktadır. Bu noktada, ülkenin ihtiyacı kadar enerji üretilirken, doğal varlıkları korumaya ve kırsal alanlarda tarım, ekoturizm, agroturizm vb. görece çevre/doğa dostu ve yerel sürdürülebilir kalkınmayı destekleyici politikalara ihtiyaç duyulduğu söylenebilir.

Özellikle yenilenebilir enerji türü olan RES’lerin yer seçim problemleri, karar verme süreçlerine katılım eksikliği ve tür- bin sayısı fazlalığından kaynaklı olumsuz dışsallıklar (ör. gürültü, çevre kirliliği) sebebiyle yerel direnişler olduğu görülmektedir (Hazar Kalonya ve Özçam, 202I). Enerji santralleri, katı atık depolama tesisi ve çöp deponi alanına karşı yapılan eylemler yerel olarak istenmeyen arazi kullanımları (LULUs) kapsamında değerlendirilebilir (Kaya ve Erol, 20I6). Bu kullanımlar olumsuz dışsallıklar sebebiyle hemen her zaman yerel halkın tepkisini çekmektedir. Bu tür kullanımlara karşı oluşan tepkinin temel sebebi yerel halkın katılım eksikliği ve yer seçim problemleridir. Bu süreçte bir başka yenilenebilir enerji türü olan güneş enerjisine karşı basına yansıyan bir hareket gerçekleşmemiş olması dikkat çekicidir. Bu kapsamda kentlerde kamu binaları önceliğinde akıllı bina sistemleriyle ve doğru yer seçim kriterleri uygulanarak güneş enerjisi santralleriyle (GES), yenilenebilir enerji projelerinin teşvik edilmesi önerilebilir. 


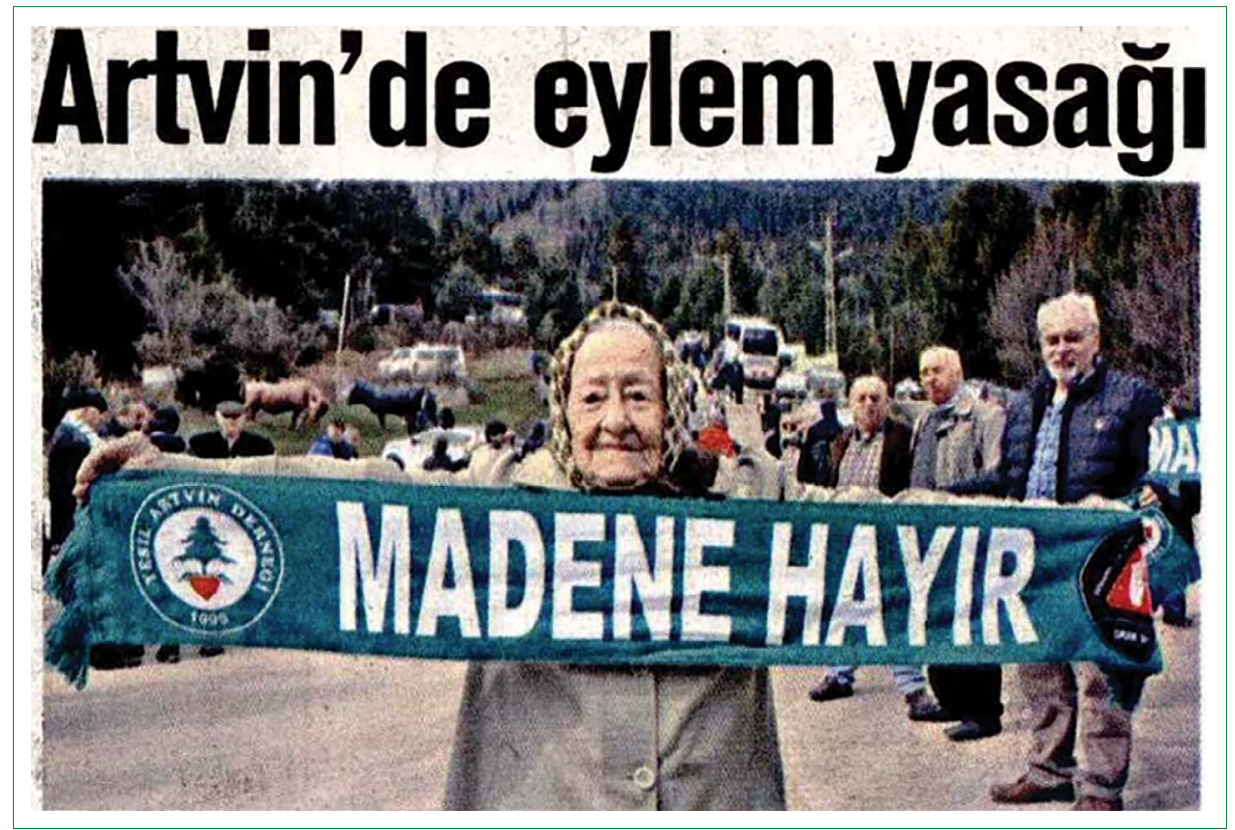

Şekil I2. Çevre hareketlerinde kadınlar, 2016.

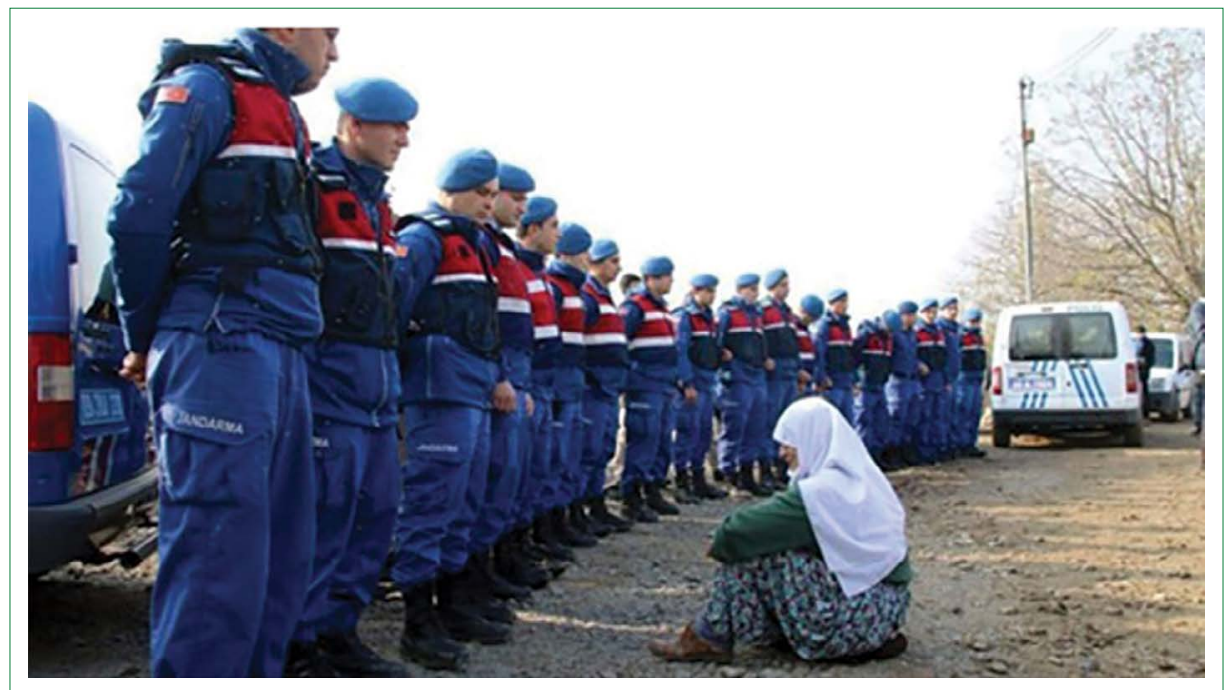

Şekil 13. Çevre hareketlerinde kadınlar, 20।7-2019.

Buna ek olarak, çevre hareketleri paralelinde süregelen hukuki süreçler, Çevre Etki Değerlendirme (ÇED) ve Sosyal Etki Değerlendirme (SED) raporlama süreçlerinin tartışmalı olduğunu göstermektedir. ÇED ve SED raporlama süreçlerinde Avrupa Çevre Ajansı'nın kullandığı performans gösterimi yaklaşımı; DPSIR (faktör, baskı, durum, etki ve tepki), esnek ve hızlı geri bildirime sahip olması açısından uygulanabilir (Hazar ve Velibeyoğlu, 2019). Türkiye'de yerelde örgütlenen çevre eylemlerinin sıklıkla ekolojik krizlere sebep olan durum ve etkilere karşı reaktif bir tepki olarak ortaya çıktığı görülmektedir. Buna karşın, çevreyle ilgili STK'lar ve meslek odalarının daha proaktif örgütlenmeler gerçekleştirebildiği ve projeleri henüz gerçekleşmeden iptal ettirdiği görülmektedir. Bu bağlamda, faktör ve baskı de- ğişkenlerinin proaktif bir yaklaşımla önceden tespit edilmesi ve gerekli müdahalelerin yapılması, çevre hareketlerinin ortaya çıkış sebebini de ortadan kaldırabilir.

Türkiye'de gerçekleşen çevre hareketleri sonucunda çevrecilerin çok çeşitli kazanımları ve kayıpları olmuştur ve olmaya devam etmektedir. Uluslararası eylemlere rağmen yapımı durdurulamayan İzmir/Bergama-Allianoi'deki Yortanlı ve BatmanHasankeyf'teki ve Ilısu barajları; Alakır'da iptal edilen HES projeleri örneklerden birkaçıdır.

Çevre hareketlerine toplumun her kesiminden katılımın fazlalığı, Türkiye'de doğal varlıkların neoliberal politikalar eliyle 
(yeniden) çitlendiğini gösterir niteliktedir. Hareketler çevre tahribatı gerçekleştikten sonra (ör. ağaçların kesilmesi); ya da çevre tahribatı gerçekleşmeden önce (ör. sondaj çalışmalarına başlanması) yapılabilmektedir. Bu sebepten, çevre hareketlerinin ekolojik krizler henüz ortaya çıkmadan önce, çevre/doğa koruma bağlamında proaktif müşterekleştirme pratikleri olarak dikkate alınması önemlidir.

Türkiye'de çitleme hareketlerine karşı müşterekleştirme pratiklerinin desteklenmesi, kırdan kente göçe sebebiyet veren koşulların azaltılması, kırsalda yaşam kalitesi ve aidiyetin artırılması ve biyoçeşitliliğin korunması için önemlidir. Buna ek olarak, 2012 yılında yürürlüğe giren 6360 sayılı Büyükşehir Yasası ile birçok yetkiyi elinde toplayan Belediyeler, II ve İlçe Tarım Müdürlükleri ile koordine olarak, toplumsal cinsiyet duyarlı bütçeleme ve teşvikler ile kırsalda kadın emeğinin ve yerel örtük bilginin desteklenmesi ve ekolojik müştereklerin korunması potansiyeline sahiptir. Ancak bunun için, proaktif müşterekleştirme pratiklerinde iştirakçi olacak koruyucu/iyi niyetli yerel yönetimler ile birlikte kent konseyleri gibi yeni kurumların inşasına ihtiyaç vardır. Bu iştirakler çeşitli saha çalışmaları ya da teorik tartışmalar üzerinden gerçekleşebilir. Müşterekler üzerinde daha kapsamlı araştırmalar yapılması, ekolojik müştereklerin biyoçeşitlilik için öneminin vurgulanması ve müştereklerin katılımcı planlama ve karar verme süreçlerinde doğru araçlarla temsil edilmeleri gerekmektedir.

Ekofeminist farkındalı̆̆ın ve kırsalda kadın gücünün artırılması için, kolektif eylemlilik ile mevcut sisteme karşı örgütlenebilecek bir toplumsal harekete ihtiyaç duyulmaktadır. Sıklıkla reaktif ve yerel odaklı olduğu görülen çevre hareketlerinin, müşterekler ekseninde bölgesel ya da ulusal ölçekte etkili olabilecek kolektif bir toplumsal harekete dönüşme potansiyeli ve yerelin dışından da çeşitli toplumsal grupları harekete geçirme gücü olduğu düşünülmektedir.

Türkiye'de özellikle tarımda makineleşme ile kadınlar ve erkekler arasında artan bir mülkiyet eşitsizliği, özel ve kamusal alanların artan cinsiyetçi kullanımları ve buna paralel karar verme süreçlerine kadınların katılımının kısıtlanması sonucunda, kırsalda kadın emeğini ve biyoçeşitliliği korumak için yeni stratejilere ihtiyaç duyulmaktadır (Yüksekkaya, 20I8). Bu kapsamda literatürde geliştirilen stratejilerden bazıları; (I) korunacak bitkilerin kadınların ihtiyaçlarına ve kullanımlarına göre önceliklendirilmesi, (2) kadınların geleneksel bilgi ve deneyiminin fark edilmesi, değerlendirilmesi ve teşvik edilmesi, (3) kadınların bitki ve toprak kaynaklarına erişimi için yerel haklar sistemi kurulması, (4) kadınların bitkiler üzerindeki haklarını ve refahını etkileyen her konuda üretilen politikalarda ve karar verme süreçlerinde kadınlara yer verilmesi, ve (5) bu konularda yapılan uluslararası araştırmaların artırılmasıdır (Howard, 2003).
Ekofeminist perspektiften yapılan çalışmaların hemen hepsinde teorik kavramsallaştırmaların yanı sıra, Afrika, Hindistan, Meksika ve Nepal gibi az gelişmiş/gelişmekte olan ülkelerin kırsal bölgelerinde yapılan saha çalışmaları dikkat çekmektedir. Bu çalışmalarda kırsal alanlarda kadınların durumu, yerele özgü değerler ve ulusal mevzuatlara göre farklılık gösterse de toplumsal cinsiyete dayalı kesişimsellikler ile derinleşerek benzer sonuçlar ortaya çıkarabilmektedir. Gelişmekte olan bir ülke olarak Türkiye'de de çevre hareketlerine katılan kadınların durumu, ikinci ayrım ekofeminist yaklaşımın işaret ettiği gibi, kırsal ve kentsel alanlarda ataerkil gelenekten kaynaklanan toplumsal cinsiyet eşitsizliğine ek olarak, bölgesel eşitsizlikler, ekonomik ve sosyo-kültürel eşitsizlikler, teknik ve sosyal altyapıya erişim imkanlarındaki eşitsizlikler, dinler ve etnik gruplar arasında ortaya çıkan eşitsizlikler, politik eşitsizlikler vb. kesişimsellikler bağlamında incelenmeye ihtiyaç duymaktadır. Bu kesişimsellikler özellikle farklı coğrafi bölgelerde, kırsal ve kentsel alanlarda çevre hareketlerine katılan kadınların motivasyonları arasındaki benzerlik ve farklılıkların ortaya konulması açısından önemlidir.

Bu kapsamda ileride yapılacak çalışmalarda, Türkiye'de kadınların çevre hareketlerindeki yerine dair yapılan medya taramasının güncellenmesi ve ikinci ayrım ekofeminist perspektiften kırsalda kadın emeğinin ve sosyo-doğal toplulukların detaylıca inceleneceği saha çalışmaları ve projeler geliştirilmesi önerilmektedir. Buna ek olarak, çalışma kapsamında Türkiye'deki çevre hareketleriyle ilgili oluşturulan mekânsal veri tabanının, ilgili bir meslek odası ve/veya çevre derneğinin internet sitesinde güncellenebilir bir açık kaynak (soyut müşterek) olarak paylaşılması önerilmektedir.

\section{Teşekkür}

Yazar, çevre hareketleriyle müşterekleştirme pratiklerine katkıda bulunan eylemcilere, meslek odalarına ve sivil toplum kuruluşlarına teşekkür eder. Bu çalışma, Pamukkale Üniversitesi Bilimsel Araştırma Projeleri Komisyonu Başkanlığı tarafından 2020BSP005 nolu proje ile desteklenmiştir. 


\section{KAYNAKLAR}

Agarwal, B. (1992). The gender and environment debate: Lessons from India. Feminist studies, 18(1), 119-158.

Agrawal, A. (2003). Sustainable Governance of Common-Pool Resources: Context, Methods and Politics, Annual Review of Anthropology 32: 243262. DOI: https://doi.org/10.1146/annurev.anthro.32.061002.093112.

Ahlers, R., \& Zwarteveen, M. (2009). The Water Question in Feminism: Water Control and Gender Inequities in a Neo-Liberal Era, Gender, Place \& Culture 16 (4): 409-426. DOI: 10.1080/09663690903003926.

Akbulut, B. (2014). Küresel, Özel ve Kamusal Mallar, Erişim tarihi: 14.04.2015, 5. Yeşil Ekonomi Konferansı, İstanbul. http://tr.boell.org/ tr/2014/11/05/kuresel-ozel-ve-kamusal-mallar.

Angus, I. (2008). The Myth of the Tragedy of the Commons. https://climateandcapitalism.com/2008/08/25/debunking-the-tragedy-of-thecommons.

Benlisoy, S. (2014). Müşterekler Üzerinde Piyasa Baskısı. Erişim tarihi: 14.04.2015, http://tr.boell.org/tr/2014/11/05/musterekler-uzerindepiyasa-baskisi. 5. Yeşil Ekonomi Konferansı, İstanbul.

Berkay, F. (2010). Kadınlar Doğaya Sahip Çıkıyor Kadinlar Ekolojik Donusumde içinde (ed. E. Degirmenci), Yeni İnsan Yayınevi, İstanbul.

Biehl, J. (1991). Finding Our Way: Rethinking Ecofeminist Politics, Black Rose Books, Montreal.

Bollier, D., \& Helfrich, S. (2015). Patterns of Commoning. Amherst, MA; Jena, Germany; Chiang Mai, Thailand: the Commons Strategies Group.

Breton, M. J. (1998). Women pioneers for the environment. Boston: Northeastern University Press.

Castree, N., \& Braun, B. (Ed.). (1998). Remaking Reality: Nature at the Mil lenium (p. 3). London: Routledge.

Castree, N., \& Braun, B. (2001). Social nature, Malden, MA: Blackwell Publishing.

Christophers, B. (2018). The new enclosure: The appropriation of public land in neoliberal Britain. Verso Trade.

Clement, F., Harcourt, W. J., Joshi, D., \& Sato, C. (2019). Feminist political ecologies of the commons and commoning. International Journal of the Commons, 13(1), 1-15

Çetin, O. B. (2005). Ekofeminizm: Kadın Doğa İlişkisi ve Ataerkillik. Sosyoekonomi, $1(1)$.

Çetinkaya, Y. D. (2008). Toplumsal hareketler: Tarih, Teori ve Deneyim, 575, İletişim Yayınları, 2018

De Angelis, M. (2007). The Beginning of History: Value Struggles and Global Capital. London: Pluto Press.

De Angelis, M., \& Harvie, D. (2014). The commons. The Routledge Companion to Alternative Organization, London: Routledge, 280-294.

Deda, P., \& Rubain, R. (2004). Women and biodiversity: The long journey from users to policy-makers. Natural Resources Forum 28, 201-204.

Değirmenci, E. (2010). Kadınlar Ekolojik Dönüşümde, (E. Değirmenci, Der.) Yeni İnsan Yayınevi, İstanbul.

Dobson, A. (1995). Green political thought. Routledge.

Elmhirst, R. (2011). Introducing new feminist political ecologies. Geoforum, 42(2), 129-132.

Federici, S. (2011). Feminism and the Politics of the Commons. The Commoner, 24, http://www.commoner.org.uk/?p=113, Erișim tarihi: 10.06.2019.

Garner, R. (1996). Environmental politics, Prentice Hall/Harvester Wheatsheaf.

Gibson-Graham, J. K., Cameron, J., \& Healy, S. (2016). Commoning as a Postcapitalist Politics. Releasing the Commons: Rethinking the Future of the Commons (Amin, A. ve Howell, P. ed.). 192-212. New York: Routledge.

Harris, L. M. (2009). Gender and Emergent Water Governance: Comparative Overview of Neoliberalized Natures and Gender Dimensions of Privati- zation, Devolution and Marketization. Gender, Place and Culture 16(4): $387-408$

Hardin, G. (1968). The tragedy of the commons, Science, 162 (3859), 1243 1248 .

Harvey, D. (2012). Rebel cities: From the right to the city to the urban revolution. Verso books.

Hazar, D., \& Velibeyoğlu, K. (2019). Sustainable Management of Rural-Ecological Commons: Recommendations on eDPSIR Causal Networks, JEPE Journal of Environmental Protection and Ecology Vol. 20, No.1, sf. 348-357.

Hazar, D. (2020). Women in the Axis of the Enclosure of Rural-Ecological Commons, Academic Studies in Architecture, Planning and Design, Gece Publishing, 25-54.

Hazar Kalonya, D. \& Özçam, Z. (2021). Wind Farm Conflicts on the RuralEcological Commons: The Case of Karaburun, Online Journal of Art and Design Vol. 9 (1), 294-313.

Hermodsson, E. (1984). Interview: Uppsala, International Business Week, 75-58.

Heynen, N., Kaika, M., \& Swyngedouw, E. (2006). Urban political ecology. In the nature of cities: Urban political ecology and the politics of urban metabolism. Routledge, 1-20.

Howard, P. (2003). The major importance of 'minor' resources: Women and plant biodiversity. London, UK: International Institute for Environment and Development (IIED).

Kadirbeyoglu, Z. (2010). Yerel Direnis ve Değisim: Bergama Örnegi Kadinlar Ekolojik Donusumde içinde (ed. E. Degirmenci), Yeni İnsan Yayınevi, İstanbul.

Kaya, I. A., \& Erol, N. K. (2016). Conflicts over Locally Unwanted Land Uses (LULUs): reasons and solutions for case studies in Izmir (Turkey). Land Use Policy, 58, 83-94.

Krauss, C. (1993). Women and toxic waste protests: Race, class and gender as resources of resistance. Qualitative Sociology, 16(3), 247-262.

Linebaugh, P. (2008). The Magna Carta Manifesto. Berkeley: University of California Press.

Marx, K. (1867). Kapital Birinci Cilt. (Sol Yayınları, 2011), 26-27.

Matthew, R. A. (2002). Environment, Population and Conflict: New Modalities of Threat and Vulnerability in South Asia, Journal of International Affairs, 235-254.

McCright, A. M., \& Xiao, C. (2014). Gender and environmental concern: Insights from recent work and for future research. Society $\&$ Natural Resources, 27(10), 1109-1113.

Mies, M., \& Shiva, V. (1993). Ecofeminism. London: Zed Books.

Mies, M., Bennholdt-Thomsen, V., \& Von Werlhof, C. (1988). Women: The last colony. Zed Books.

Mohai, P. (1992). Men, women, and the environment: An examination of the gender gap in environmental concern and activism. Society \& Natural Resources, 5(1), 1-19.

Mollett, S., \& Faria, C. (2013). Messing with gender in feminist political ecology. Geoforum, 45, 116-125.

Mothoagae, I. D. (2016). Reclaiming our black bodies: reflections on a portrait of Sarah (Saartjie) Baartman and the destruction of black bodies by the state. Acta Theologica, 36, 62-83.

MTM (2020). Medya Takip Merkezi medya analizi, https://www.medyatakip.com.tr, Erişim tarihi: 22.11.2020.

Nightingale, A. J. (2019). Commoning for inclusion? Political communities, commons, exclusion, property and socio-natural becomings, International Journal of the Commons, 13(1), 16-35.

Ostrom, E. (1990). Governing the commons: the evolution of institutions for collective action, Cambridge University Press.

Ostrom, E. (2010). Beyond markets and states: polycentric governance of complex economic systems, Transnational Corporations Review 2.2, $1-12$. 
Penpecioğlu, M. (2013). Large-Scale Urban Projects, Production of Space and Neo-liberal Hegemony: A Comparative Study of Izmir, Megaron, 8(2), 97.

Peterson, A., \& Merchant, C. (1986). 'Peace with the earth:' Women and the environmental movement in Sweden, Women's studies International forum (Vol. 9, No. 5-6, pp. 465-479). Pergamon.

Rocheleau, D. E. (1995). Gender and biodiversity: A feminist political ecology perspective. IDS bulletin, 26(1), 9-16.

Rocheleau, D., Thomas-Slayter, B., \& Wangari, E. (1996). Gender and Environment: A Feminist Political Ecology Perspective (Rocheleau, D., Thomas-Slayter, B. ve Wangari, E. ed.), Feminist Political Ecology: Global Issues and Local Experiences, 3-26. New York: Routledge.

Rocheleau, D. (2008). Political Ecology in the Key of Policy: From Chains of Explanation to Webs of Relation. Geoforum 39(2): 716-727. DOI: 10.1080/0033 0124.2011.601193.

Roussopoulos, D. (2015). Politik Ekoloji: İklim Krizi ve Yeni Toplumsal Gündem. (F. D. Elhüseyni, Çev.). Sümer Yayıncılık, İstanbul.

Santos Junior, O. A. (2014). Urban common space, heterotopia and the right to the city: reflections on the ideas of Henri Lefebvre and David Harvey, urbe. Revista Brasileira de Gestão Urbana 6 (2), 146-157.

Sato, C., \& Alarcon, J. S. (2019). Toward a postcapitalist feminist political ecology's approach to the commons and commoning, International Journal of the Commons, 13(1), 36-61.

Seçkin, E. (2016). An Analysis of Selected Cases of Environmental Movements in Turkey through an Ecofeminist Approach. Yüksek Lisans Tezi, Orta Doğu Teknik Üniversitesi, Ankara.

Shiva, V. (1992). Women's Indigenous Knowledge and Biodiversity Conservation. India International Centre Quarterly Vol. 19 No. 1/2, Indigenous Vision: Peoples of India Attitudes to the Environment (Spring-Summer 1992), 205-214.

Stavrides, S. (2016). Common space: The city as commons. Zed Books Ltd.

Stavrides, S. (2020). The Right to the City-as-Common, $8^{\text {th }}$ November World Town Planning Day Colloqium, UCTEA Chamber of City Planners, https: / $/$ www.youtube.com/watch?v=9OiuvfNJvSk\&feature $=$ share $\& \mathrm{fb}$ clid=IwAR3Gpbojt1ajXmWWQrQNMsIwz6bclKOoWM-HjppaSPi X6RQfhF9Mdb9dRCs, Access date: 08.11.2020.

Sultana, F. (2009). Fluid Lives: Subjectivities, Gender and Water in Rural Bangladesh. Gender, Place \& Culture 16(4): 427-444. DOI:https://doi. org/10.1080/09663690903003942.

Tindall, D. B., Davies, S., \& Mauboules, C. (2003). Activism and conservation behavior in an environmental movement: The contradictory effects of gender. Society \& Natural Resources, 16(10), 909-932.

Türk, Ö. (2018). Yeni Toplumsal Hareketlerde Kadın Olmak Üzerine Türkiye'den Bir Örnek, Yüksek Lisans Tezi, İstanbul Bilgi Üniversitesi, İstanbul.

Ulusal Tez Merkezi (2020). Tez arşivi, https://tez.yok.gov.tr/UlusalTezMerkezi/, Erişim tarihi: 10.12.2020.

Wägner, E., \& Tamm, E. (1941). Fred med jorden [Peace with the Earth]. Stockholm: Albert Bonniers.

Wägner, E. (1941). Väckarklocka [Alarmclock]. Stockholm: Albert Bonniers, 1978.

Walljasper, J. (2014). "On the commons", in Müştereklerimiz, Paylaştığımız Her Şey, ed. Bengi Akbulut, Metis Press, İstanbul, 25-26.

Yüksekkaya, Ö. (2018). Rural Women In Turkey (1923-): An Examination of The Transformation of Agriculture and the Environment in Turkey Through Gender Lenses. Yüksek Lisans Tezi, Orta Doğu Teknik Üniversitesi, Ankara.

Zelezny, L., \& Bailey, M. (2006). A call for women to lead a different environmental movement. Organization \& environment, 19(1), 103-109.

Zein-El Abdin, E. (1996). Development, gender, and the environment: Theoretical or contextual link? Toward an institutional analysis of gender. Journal of economic issues, 30(4), 929-947.
Zweifel, H. (1997). The Gendered Nature of Biodiversity Conservation. NWSA Journal Vol. 9 No.3, Women, Ecology, and the Environment, sf.107-123.

Url-1: Chipko Hareketi, Hindistan, https://kuzeyormanlari.org/2015/11/ 11/agaclara-sarilarak-onlari-koruyan-cesur-yurekliler/, Erişim tarihi: 26.02.2019.

Url-2: Yeşil Kuşak Hareketi, Kenya, http://www.womenaid.org/press/info/ development/greenbeltproject.html, Erişim tarihi. 16.11.2020.

Url-3: Bergama Altın Madeni Direnişi, https://bianet.org/bianet/siyaset/ 160766-bergama-altin-madeni-direnisi-topragin-bekcileri, Erişim tarihi: 22.11.2020. 